Short communication

\title{
Novel cinnamic acid/4-aminoquinoline conjugates bearing non-proteinogenic amino acids: Towards the development of potential dual action antimalarials
}

\author{
Bianca C. Pérez ${ }^{\mathrm{a}, 1}$, Cátia Teixeira ${ }^{\mathrm{a}, \mathrm{b}, 1}$, Marta Figueiras ${ }^{\mathrm{a}}$, Jiri Gut ${ }^{\mathrm{c}}$, Philip J. Rosenthal ${ }^{\mathrm{c}}$, José R.B. Gomes ${ }^{\mathrm{b}}$, \\ Paula Gomes ${ }^{\mathrm{a}, *}$ \\ ${ }^{a}$ Centro de Investigação em Química da Universidade do Porto, Departamento de Química e Bioquímica, Faculdade de Ciências, Universidade do Porto, R. do Campo Alegre, 687, \\ P-4169-007 Porto, Portugal \\ ${ }^{\mathrm{b}}$ CICECO, Departamento de Química, Universidade de Aveiro, Campus Universitário de Santiago, 3810-193 Aveiro, Portugal \\ ${ }^{\mathrm{c}}$ Department of Medicine, San Francisco General Hospital, University of California, CA 94143-0811, USA
}

\section{H I G H L I G H T S}

- Cinnamic acid/4-aminoquinoline hybrids were synthesized as dualaction drugs.

- Hybrids were linked via a retroenantio dipeptide. Its absence was also evaluated.

- Their power to inhibit hemozoin growth, falcipain and blood-stage Pf were assessed.

- Hybrids with dipeptide were active against blood-stage Pf and hemozoin growth.

- Molecules without spacer were better falcipain-2 inhibitors.

\section{A R T I C L E I N F O}

\section{Article history:}

Received 12 March 2012

Received in revised form

11 May 2012

Accepted 15 May 2012

Available online 28 May 2012

\section{Keywords:}

Antimalarials

Blood-schizontocidal

Chloroquine

Cinnamic acid derivatives

Molecular modeling studies

\section{G R A P H I C A L A B S T R A C T}

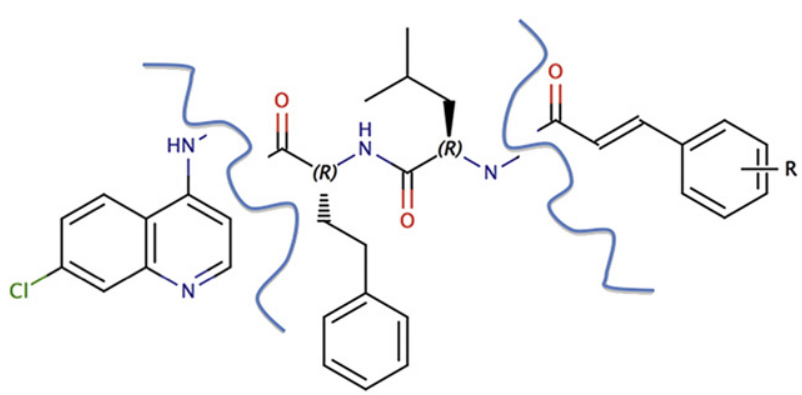

\begin{abstract}
A B S T R A C T
A series of cinnamic acid/4-aminoquinoline conjugates conceived to link, through a proper retro-enantio dipeptide, a heterocyclic core known to prevent hemozoin formation, to a trans-cinnamic acid motif capable of inhibiting enzyme catalytic Cys residues, were synthesized as potential dual-action antimalarials. The effect of amino acid configuration and the absence of the dipeptide spacer were also assessed. The replacement of the $D$-amino acids by their natural $L$ counterparts led to a decrease in both anti-plasmodial and falcipain-inhibitory activity, suggesting that the former are preferable. Molecules with such spacer were active against blood-stage Plasmodium falciparum, in vitro, and hemozoin formation, implying that the dipeptide has a key role in mediating these two activities. In turn, compounds without spacer were better falcipain-2 inhibitors, likely because these compounds are smaller and have their vinyl bonds in closer vicinity to the catalytic Cys, as suggested by molecular modeling calculations. These novel conjugates constitute promising leads for the development of new antiplasmodials targeted at blood-stage malaria parasites.
\end{abstract}

(c) 2012 Elsevier Masson SAS. All rights reserved.

Abbreviations: AA, amino acid; ABC, adenosine triphosphate binding cassette; $\mathrm{CQ}$ chloroquine; DCM, dichloromethane; DFT, density functional theory; DIEA, $N, N$-dii-

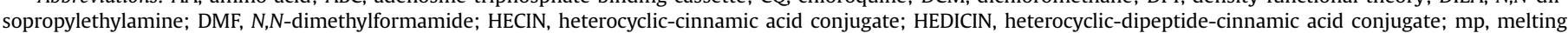

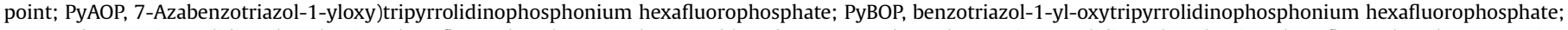

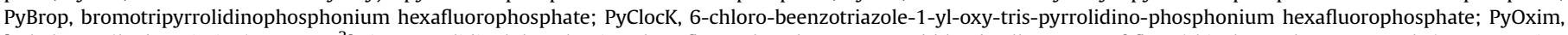

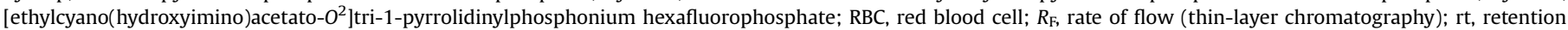
time; SAR, structure-activity relationships; TBTU, $O$-(benzotriazol-1-yl)- $N, N, N^{\prime}, N^{\prime}$-tetramethyluronium tetrafluoroborate; THF, tetrahydrofurane.

* Corresponding author. Tel./fax: +351 220402563.

E-mail address: pgomes@fc.up.pt (P. Gomes).

1 These authors contributed equally to this work. 


\section{Introduction}

Malaria remains one of the most important infectious diseases in the world. Plasmodium falciparum, the most virulent species of human malaria parasite, is responsible for about 1 million deaths every year [1-3]. Once having invaded the human host through the bite of an infected female Anopheles mosquito, the parasites replicate silently in the liver, after which they invade red blood cells (RBCs), where a second asexual reproduction cycle gives rise to the clinical symptoms of the disease. P. falciparum causes the most severe clinical manifestations of malaria, and is particularly deadly to children under five years old, so impairment of development of blood-stage $P$. falciparum has been the main target in antimalarial chemotherapy [4-6].

Within infected RBCs, parasites digest host hemoglobin to obtain free amino acids required for parasite nourishment and development [7-9]. In this process, free heme is produced as a side product that is toxic to the parasite. Hence, the parasite converts free heme into a polymer, hemozoin, which is a non-toxic insoluble biocrystal [8]. The classical antimalarial chloroquine (CQ) blocks hemozoin formation and consequently kills malaria parasites $[8,10]$.

Inhibition of blood-stage $P$. falciparum may be also achieved through starvation, i.e., by inhibiting parasitic enzymes involved in globin degradation. Amongst them, cysteine proteases, especially falcipain-2 (FP2) and falcipain-3 (FP3), are key therapeutic targets [7]. Therefore, compounds able to simultaneously impair hemozoin formation and falcipain proteolytic activity may be potent agents against blood-stage plasmodia with reduced propensity to elicit parasite resistance [11]. In this regard, this paper provides the synthesis, in silico study and in vitro evaluation of novel cinnamic acid/4-aminoquinoline conjugates ( $\mathbf{8}$ and $\mathbf{9}$, Scheme 1 ) as potential dual action antimalarials. These conjugates, named HEDICINs (8, Scheme 1) and HECINs (9, Scheme 1) were conceived as potential inhibitors of both falcipain protease activity and hemozoin formation, according to the rationale below.

\subsection{Rationale}

HEterocyclic-DIpeptide-CINnamic acid conjugates (HEDICINs) were designed to link, through a suitable spacer, (i) the CQ heterocyclic core, known as relevant to inhibit hemozoin formation [12,13], to a (ii) trans-cinnamic acid motif, as cinnamic acids have been described to exhibit both antimalarial activity [14] and inhibiting enzyme catalytic Cys residues [15]. Cinnamic acid derivatives, due to their $\alpha, \beta$-unsaturated carbonyl moiety, can act as Michael acceptors and inhibit cysteine proteases through $S$-alkylation $[9,16,17]$. Irreversible $S$-alkylation of the falcipain catalytic Cys has been considered the major mechanism behind the inhibitory and in vitro anti-plasmodial activity of peptidyl inhibitors including leupeptin and vinyl sulfones developed by Rosenthal and co-workers (Fig. 1) $[9,18]$. The most active vinyl sulfones contained a dipeptide Leu$h$ Phe spacer between a bulky moiety and the $S$-alkylating motif [9,18-20]. Unfortunately, peptide-based inhibitors are prone to proteolytic degradation [21], a problem that can be overcome by use of suitable peptide delivery systems $[22,23]$. Still, such systems are likely to impair efficient inhibition of the target enzyme.

One way to circumvent the limitations of peptidyl inhibitors is the use of retro-enantio peptides, i.e., analogs where all amino acids have a D configuration and are assembled in reversed order [24,25]. As these molecules have native side chain topology but reversed amide bonds, they theoretically allow enzyme-ligand contacts identical to those displayed by native peptides, while eluding recognition by other proteases (Fig. 1).

The retro-enantio analog of Leu- $h$ Phe seems the best mimic of falcipain P2-P1 sites, linking the putative P3 motif (heterocyclic core of CQ) to the Michael acceptor in P1' (cinnamic acid). However,

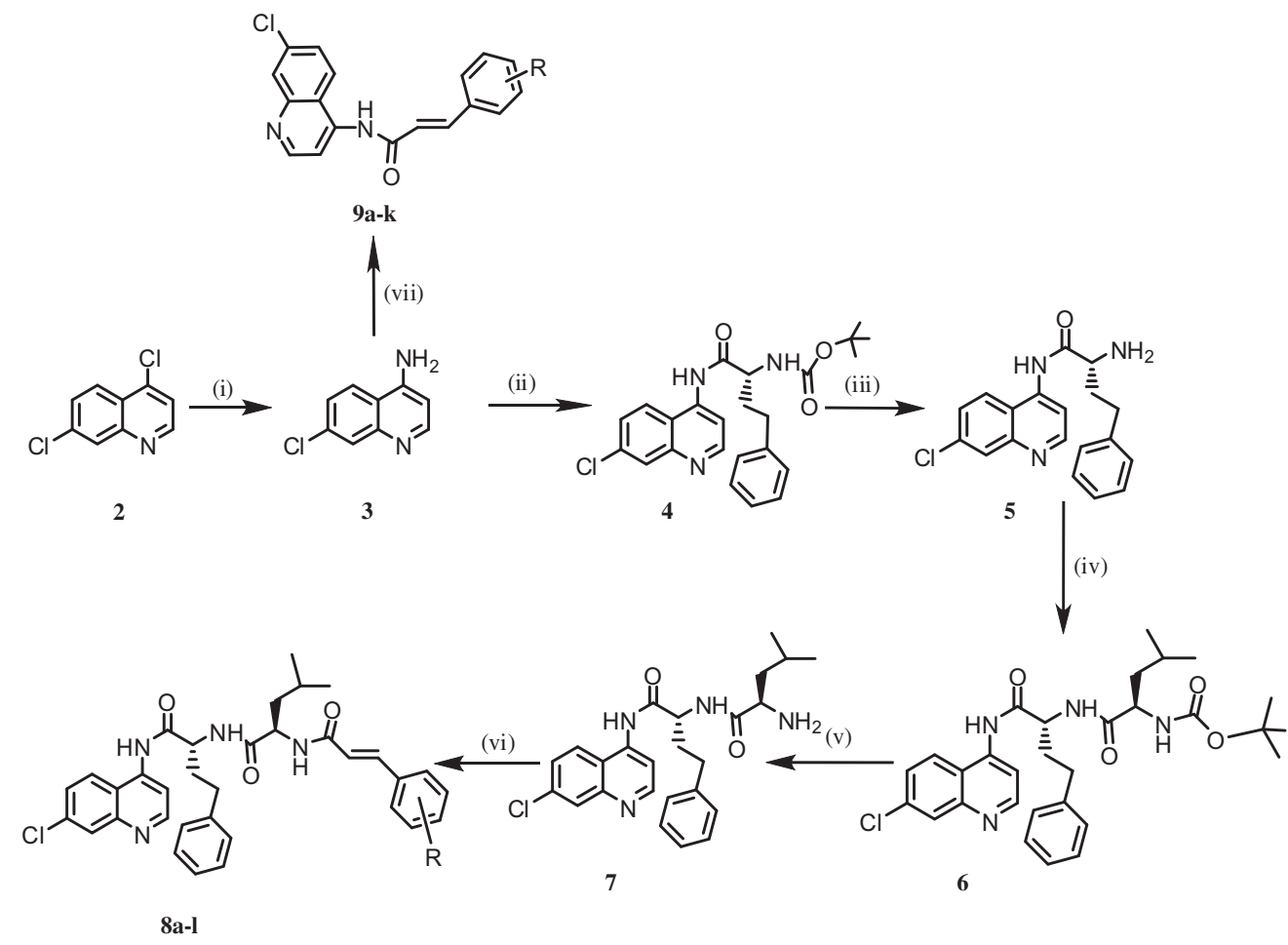

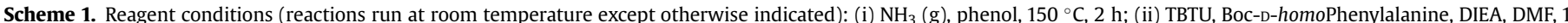

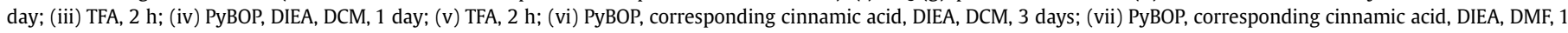
day. Substituents R, in both HEDICINs 8a-1 and HECINs $\mathbf{9 a - k}$, are given on Table 1. 


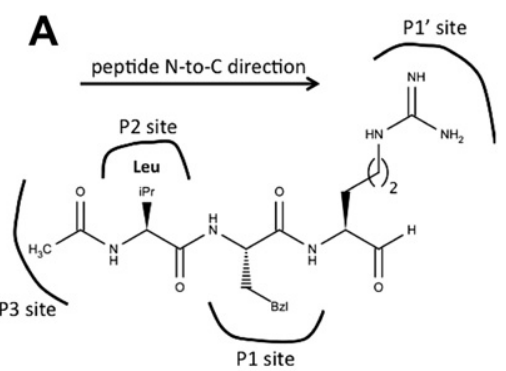

\section{B}<smiles>CCC[C@@H](C)NC(=O)[C@H](C)NC(=O)[C@H](C)N[C@@H](/C=C/S(=O)(=O)c1ccccc1)CBr</smiles>

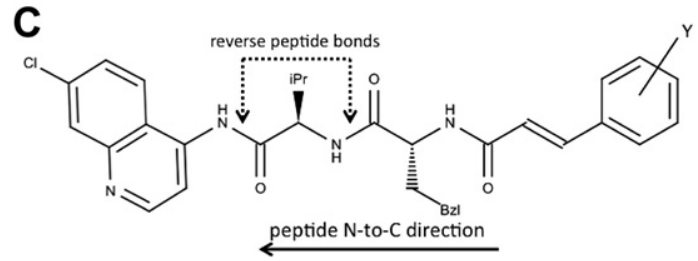

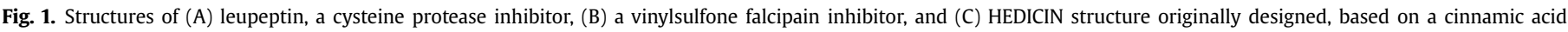
building block linked to the chloroquine's hetereocyclic core through the retro-enantio analog of Leu- $h$ Phe (see text).

preliminary computational studies by our group on HEDICINs $\mathbf{1}$ and $8 f$ (structures given below, Fig. 2A and B, respectively), differing only in the order of the two D-amino acids, suggested that the inverse sequence, i.e., D- $h$ Phe-D-Leu, would allow a closer approximation of the electrophilic moiety to the catalytic center (Fig. S1).

These preliminary observations in silico were later supported in vitro by anti-plasmodial activity tests against the CQ-resistant Plasmodium falciparum strain W2, which revealed that 1 did not display any antimalarial activity up to $10 \mu \mathrm{M}$, while $8 \mathbf{f}$ inhibited parasite development with an $\mathrm{IC}_{50}$ of $5.43 \mu \mathrm{M}$ (Table 1 ). Therefore, we engaged in the synthesis of HEDICINs with general structure 8 (Scheme 1) as potential dual-action drugs against bloodstage parasites. Analogs lacking the dipeptide spacer, HECINs 9 (Scheme 1), were also prepared to assess the relevance of that spacer. Compounds $\mathbf{8}$ and $\mathbf{9}$ were evaluated in vitro concerning their ability to inhibit (i) heme polymerization to hemozoin; (ii) falcipain activity; and (iii) development of blood-stage P. falciparum. In order to support observed SAR and to rationalize the activity profile of the novel compounds, we also performed molecular modeling calculations on computational models derived from X-ray structures of FP2 (PDB code: 3BPF) and FP3 (PDB code: 3BWK) co-crystalized with E64 and K11017, respectively [7,16].

\section{Results and discussion}

\subsection{Chemical synthesis}

Twenty-three novel compounds, $\mathbf{8 a}-\mathbf{l}$ and $\mathbf{9 a}-\mathbf{k}$, were successfully obtained in high purity and with correct spectral and analytical data, as described in the Experimental section. Global synthesis yields were modest, due to the low nucleophilicity of the aniline group in 4-amino-7-chloroquinoline (3), a problem that persisted even when using highly effective coupling agents such as PyBroP, PyClocK, PyAOP or PyOxim [26] in step (ii) of Scheme 1. Interestingly, even though the use of 7-aza-1-hydroxybenzotriazole derivatives as PyAOP has been reported to improve yields in couplings involving poor nucleophiles [27], the best yields in step (ii) were achieved when using the most common 1-hydroxybenzotriazole derivative, TBTU, as a coupling agent. The low nucleophilicity of the aniline 4-amino-7-chloroquinoline (3) was also likely responsible for the low yields obtained in the direct coupling of this heterocycle to cinnamic acid derivatives, step (vii) in Scheme 1. In this case, the best results were achieved using PyBOP as a coupling agent. The L-amino acid analog of $\mathbf{8 a}$, compound $\mathbf{1 0 a}$, was also prepared by similar methods.

\subsection{In vitro studies}

\subsubsection{Inhibition of heme polymerization}

The capacity of test compounds $\mathbf{8}$ and $\mathbf{9}$ to inhibit heme polymerization in vitro was assessed by previously reported methods $[28,29]$, given in detail under Experimental. The assays were run in 96-well microplates, where negative controls (water, DMSO) and positive controls ( $1 \mathrm{mM} \mathrm{CQ}$ ) were included. Test compounds were assayed at $1 \mathrm{mM}$ and data are given in Table 1 . Interestingly, the dipeptide spacer was required to block heme polymerization, i.e., while HECINs 9 were not active, HEDICINs 8 displayed variable inhibitory efficiencies, with four out of the twelve compounds
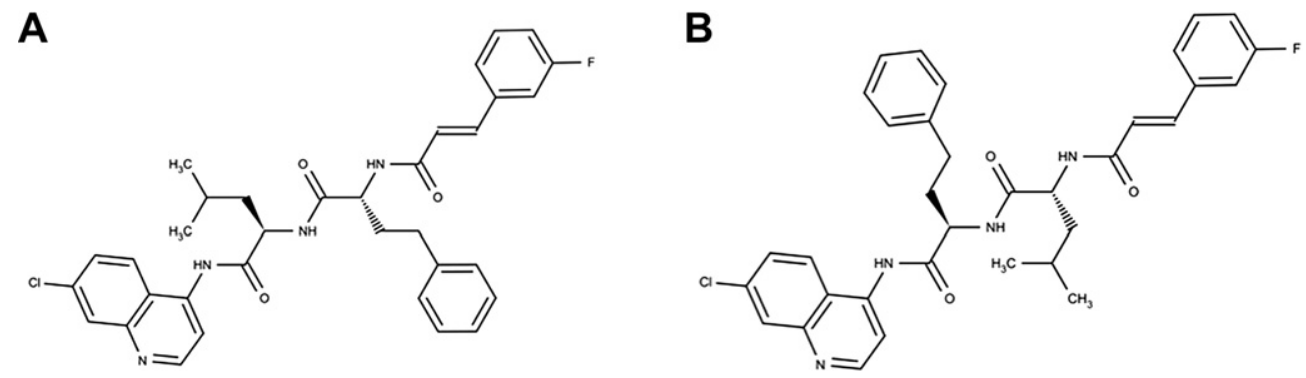

Fig. 2. Structures of compounds $\mathbf{1}$ (A, left) and $\mathbf{8 f}$ (B, right). 
Table 1

In vitro data on test compounds, HEDICINs (8) and HECINs $(\mathbf{9})$. Compound 10a, the Lamino acid analog of $\mathbf{8 a}$, is also included.

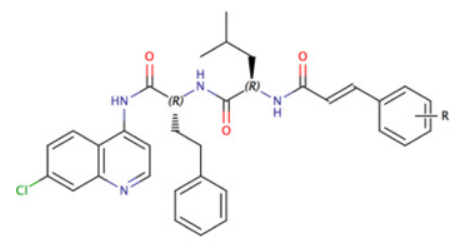

8a-l

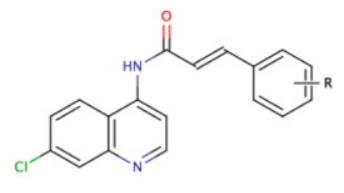

9a-k

\begin{tabular}{|c|c|c|c|c|c|c|}
\hline Compound & $\mathrm{R}$ & $\begin{array}{l}\text { Hemozoin } \\
\text { Inhibition }^{\mathrm{a}}\end{array}$ & $\begin{array}{l}\mathrm{IC}_{50} \text { Pf } \mathrm{W} 2^{\mathrm{b}} \\
(\mu \mathrm{M})\end{array}$ & $\begin{array}{l}\mathrm{IC}_{50} \mathrm{FP}^{\mathrm{C}} \\
(\mu \mathrm{M})\end{array}$ & $\mathrm{IC}_{50} \mathrm{FP} 3(\mu \mathrm{M})$ & $\log \mathrm{P}^{\mathrm{d}}$ \\
\hline $8 a$ & $\mathrm{H}$ & - & 4.89 & 19.6 & $>50$ & 6.6 \\
\hline $10 a^{e}$ & $\mathrm{H}$ & $N D^{f}$ & 8.00 & 50.0 & ND & 6.6 \\
\hline $8 b$ & $p$-Me & ++ & 1.96 & $>50$ & ND & 7.1 \\
\hline $8 c$ & $p-{ }^{i} \operatorname{Pr}$ & - & 0.830 & $>50$ & ND & 7.9 \\
\hline $8 d$ & p-OMe & + & 10.8 & $>50$ & ND & 6.5 \\
\hline $8 e$ & $p-\mathrm{NH}_{2}$ & ++ & 3.28 & 20.3 & $>50$ & 5.8 \\
\hline $8 f$ & $m-\mathrm{F}$ & - & 5.43 & 23.1 & $>50$ & 6.8 \\
\hline $8 g$ & $p-\mathrm{F}$ & - & 4.67 & 50.0 & ND & 6.8 \\
\hline $8 h$ & $p-\mathrm{Cl}$ & - & 2.89 & $>50$ & ND & 7.2 \\
\hline $8 \mathbf{i}$ & $p-B r$ & - & 2.55 & 48.3 & $>50$ & 7.4 \\
\hline $8 \mathbf{j}$ & $o-\mathrm{NO}_{2}$ & + & 1.66 & $>50$ & ND & 6.6 \\
\hline 8k & $m-\mathrm{NO}_{2}$ & - & 2.10 & 28.1 & $>50$ & 6.6 \\
\hline 81 & $p-\mathrm{NO}_{2}$ & ++ & 1.23 & $>50$ & ND & 6.6 \\
\hline 9a & $\mathrm{H}$ & - & $>10$ & $>50$ & ND & 4.3 \\
\hline 9b & $p$-Me & - & $>10$ & 28.5 & $>50$ & 4.8 \\
\hline 9c & $p-{ }^{i} \operatorname{Pr}$ & - & $>10$ & $>50$ & ND & 5.6 \\
\hline 9d & p-OMe & - & $>10$ & $>50$ & ND & 4.2 \\
\hline $9 e$ & $m-\mathrm{F}$ & - & $>10$ & $>50$ & ND & 4.5 \\
\hline 9f & $p-F$ & - & $>10$ & $>50$ & ND & 4.5 \\
\hline $9 g$ & $p-\mathrm{Cl}$ & - & $>10$ & 41.3 & $>50$ & 4.9 \\
\hline $9 h$ & $p-B r$ & - & $>10$ & 33.1 & $>50$ & 5.1 \\
\hline $9 \mathbf{i}$ & $o-\mathrm{NO}_{2}$ & - & $>10$ & 23.6 & $>50$ & 4.3 \\
\hline 9j & $m-\mathrm{NO}_{2}$ & - & $>10$ & 14.2 & $>50$ & 4.3 \\
\hline 9k & $p-\mathrm{NO}_{2}$ & - & $>10$ & $>50$ & ND & 4.3 \\
\hline E64 & - & ND & ND & 0.0246 & ND & \\
\hline ART & - & ND & 0.00876 & ND & ND & \\
\hline CQ & - & ++ & 0.0760 & ND & ND & \\
\hline
\end{tabular}

a Ability of the test compounds to inhibit hemozoin formation in vitro was calculated as a \% of the inhibitory effect displayed by reference drug CQ in the same experiment; test compounds were ranked as follows: $<50 \%$, not active ( - ); between 50 and $75 \%$, moderately active $(+) ; \geq 75 \%$, highly active $(++)$.

b Blood-stage anti-plasmodial activity was determined against the CQ-resistant $P$. falciparum strain W2, using artemisinin (ART) and CQ as reference drugs.

${ }^{c}$ Falcipain inhibition capacity was evaluated against falcipain-2 using E64 as reference inhibitor and only positives $\left(\mathrm{IC}_{50}<50 \mu \mathrm{M}\right)$ were further evaluated against falcipain-3.

d The $\log P$ values were estimated with the MarvinSketch software [33].

e Compound 10a is the L-amino acid analog of $\mathbf{8 a}$.

${ }^{\mathrm{f}} \mathrm{ND}$, not determined.

$(\mathbf{8 b}, \mathbf{8 e}, \mathbf{8 j}$ and $\mathbf{8 1}$ ) highly active (i.e., comparable to the reference drug, CQ). Though no clear trend could be established regarding stereoelectronic properties of the aryl substituent in compounds $\mathbf{8}$, it was clear that: (i) hydrogen (i.e., absence of a substituent) or halogens in the para position were detrimental for activity, whereas (ii) nitrogenated groups at either the ortho $\left(\mathbf{8 j}, o-\mathrm{NO}_{2}\right)$ or the para (8e, $p-\mathrm{NH}_{2} ; \mathbf{8 1}, p-\mathrm{NO}_{2}$ ) position of the aryl ring was beneficial, but (iii) detrimental if placed in the meta position $\left(\mathbf{8 k}, m-\mathrm{NO}_{2}\right)$. Furthermore, while small alkyl groups in para $(\mathbf{8 b}, p$-Me) were advantageous, bulkier groups as in $\mathbf{8 c}\left(p-{ }^{i} \mathrm{Pr}\right)$ led to complete loss of activity.

Thus, replacement of CQ's aliphatic chain by an adequate dipeptidyl-cinnamoyl moiety as in $\mathbf{8 b}, \mathbf{8 e}, \mathbf{8 j}$ and $\mathbf{8 1}$ appears to preserve the parent drug's ability to inhibit hemozoin formation, suggesting that these novel compounds could be promising leads for new CQ surrogates.

\subsubsection{Anti-plasmodial activity}

Activity against blood-stage CQ-resistant $P$. falciparum strain W2 was assessed as previously reported [30] and given in detail in Experimental. Results demonstrated a complete lack of activity displayed by HECINs 9, correlating with their inability to inhibit heme polymerization (Table 1). In turn, eleven out of the twelve HEDICINs 8 had $\mathrm{IC}_{50}$ values under $10 \mu \mathrm{M}$. Interestingly, three of the four most active HEDICIN blockers of heme polymerization $(\mathbf{8 b}, \mathbf{8 j}$ and $\mathbf{8 1}$ ) were also among the four most active antiplasmodials, with $\mathrm{IC}_{50}$ below $2 \mu \mathrm{M}$. These results suggest that inhibition of heme polymerization is, at least in part, responsible for the anti-plasmodial activity of HEDICINs.

An obvious exception to correlation between inhibition of heme polymerization and anti-plasmodial activity in HEDICINs is compound $\mathbf{8 c}$; this bears a bulky electron-donating $p$-isopropyl group and did not inhibit heme polymerization in vitro, but displayed the highest anti-plasmodial activity. The inability of $\mathbf{8 c}$ to inhibit heme polymerization could be related to the bulkiness of the isopropyl group, but due to the higher hydrophobicity of this substituent, 8c was the most lipophilic HEDICIN assayed. Though we could not establish a full correlation between HEDICIN antiplasmodial activity and estimated clogP values (not shown), the markedly higher lipophilicity of $\mathbf{8 c}$, as compared to the other analogs, could promote a higher permeabilization of this compound into the infected RBC. Kirk and co-workers have demonstrated that $P$. falciparum parasites create new permeability pathways in host RBC, leading to increased permeability to small organic cations [31,32].

In summary, though clean correlations could not be drawn between the anti-plasmodial activities displayed by the different HEDICINs (8) in vitro and molecular descriptors such as stereoelectronic factors (aryl substituents) or lipophilicity, it is demonstrated that these compounds displayed anti-plasmodial activity, whereas their HECIN counterparts (9), lacking the dipeptide spacer, did not. HEDICINs (8) inhibited heme polymerization in vitro, suggesting that this inhibitory activity is at least in part responsible for their anti-plasmodial activity.

\subsubsection{Falcipain inhibition in vitro}

The very different activities of compounds $\mathbf{8}$ and $\mathbf{9}$ suggest that the retro-enantio dipeptide spacer has a relevant role in determining anti-plasmodial activity. In view of this, we hypothesized that the anti-plasmodial activity of HEDICINs could also be partly due to falcipain inhibition [9,18]. Therefore, both HEDICINs 8 and HECINs 9 were evaluated in vitro for inhibition of falcipains, using previously described methods [9], given in detail under Experimental. Only those compounds with $\mathrm{IC}_{50}<50 \mu \mathrm{M}$ against FP2 were assayed against FP3, as it has been established that FP2 has a larger catalytic cavity that accommodates a wider range of inhibitors than FP3. Consistent with this assumption, none of the compounds that inhibited FP2 in vitro displayed $\mathrm{IC}_{50}<50 \mu \mathrm{M}$ against FP3 (Table 1).

Falcipain inhibition results contrasted with those for inhibition of heme polymerization or parasite development. HECINs $\mathbf{9}$ generally displayed more potent inhibition of falcipain than did HEDICINs 8 (Table 1 ). The ability of the test compounds to inhibit FP2 did not correlate with their anti-plasmodial activity. Although none of the HECINs 9 displayed anti-plasmodial activity, many inhibited FP2 and one of them, 9j, was actually the best FP2 inhibitor amongst the test compounds. Concerning HEDICINs, 8a, $\mathbf{8 f}$ and $\mathbf{8 k}$, derived from cinnamic acid, $m$-fluorocinnamic acid, and $m$-nitrocinnamic acid, respectively, were the most active HEDICINs against FP2, with $\mathrm{IC}_{50}$ values of $19.7,23.1$ and $28.1 \mu \mathrm{M}$. Thus, stereoelectronic effects from aryl substituents did not correlate with inhibitory activities, as in HEDICINs $\mathbf{8}$ the most active compound was unsubstituted (8a), followed by the meta-fluorinated 
compound (8f); in turn, in HECINs 9, the meta-fluorinated derivative was inactive, whereas the most active of the set was $\mathbf{9 j}$, which bears a meta-nitro substituent.

The effect of amino acid configuration on HEDICIN activity was also assessed through synthesis and evaluation of $\mathbf{1 0 a}$, the L-amino acid analog of 8a; interestingly, replacement of the D-amino acids by their natural $L$ counterparts led to a clear decrease in both antiplasmodial and falcipain-inhibitory activity. Therefore, amino acid configuration does influence compound behavior as either antiplasmodial agent or falcipain inhibitor and, in the particular case of HEDICINs, data suggests that D-amino acids are preferable.

Of note, the compound with highest anti-plasmodial activity, 8c, was completely devoid of inhibitory activity against FP2. This compound likely exerts its anti-plasmodial action by mechanisms other than inhibition of hemozoin formation or falcipain activity. Data on compound 8e reinforce the idea that falcipain or hemozoin inhibition are not the main mechanisms of action responsible for HEDICINs anti-plasmodial activity: $\mathbf{8 e}$, bearing a $p$-amino substituent in the aryl ring, was the test compound which best reached our original goal of a dual-action inhibitor, by joining high hemozoin inhibitory activity with an $\mathrm{IC}_{50} \leq 20 \mu \mathrm{M}$ against FP2; however, such was not translated into the highest anti-plasmodial activity being observed for $\mathbf{8 e}$.

Taken together, data from in vitro falcipain inhibition and parasite development assays suggest that the dipeptide spacer in HEDICINs 8 promotes uptake into infected RBCs. This hypothesis could explain why HEDICINs perform better than HECINs as antiplasmodials, despite the observation that HECINs were better falcipain-inhibitors than the HEDICINs. In addition, lipophilicity could have a role in compound uptake and anti-plasmodial action, as HEDICINs $\mathbf{8}$ are more lipophilic than HECINs $\mathbf{9}$ (due to the D-Leu and the D- $h$ Phe hydrophobic side chains), and the most lipophilic compound, 8c, had the greatest anti-plasmodial activity.

\subsection{In silico studies}

A thorough computational study was undertaken in order to explain the unexpected superior ability of HECINs $\mathbf{9}$ to inhibit falcipains, as compared to HEDICINs 8, and the inability to establish any clear correlation between structure and activity of the test compounds.

\subsubsection{Molecular docking and dynamic simulations}

Docking calculations were performed to predict the structures of complexes between falcipains and the two families of compounds. The stabilities of the complexes were further evaluated by molecular dynamics simulations. Additionally, DFT calculations of Fukui indices were used to quantify electrophilicity at particular atomic sites. Molecular modeling calculations, given in detail under Experimental, were carried out on a computational model of the enzymes derived from the X-ray structures of FP2 (PDB code: 3BPF) and FP3 (PDB code: 3BWK) co-crystalized with E64 and K11017, respectively.

The computational results suggest that all test compounds, belonging to both series ( 8 and $\mathbf{9}$ ), are not able to fit into the FP3 catalytic site as efficiently as into FP2 subsites. Fig. 3 represents the preferred docking conformation of the most active inhibitor for each series (compounds $\mathbf{8 a}$ and $\mathbf{9 j}$ ) into the FP2 and FP3 catalytic sites. As we can observe, the vinyl group in 8a is placed in the S2 subsite of FP2 (Fig. 3A) while in FP3 it is located at the S2' cavity

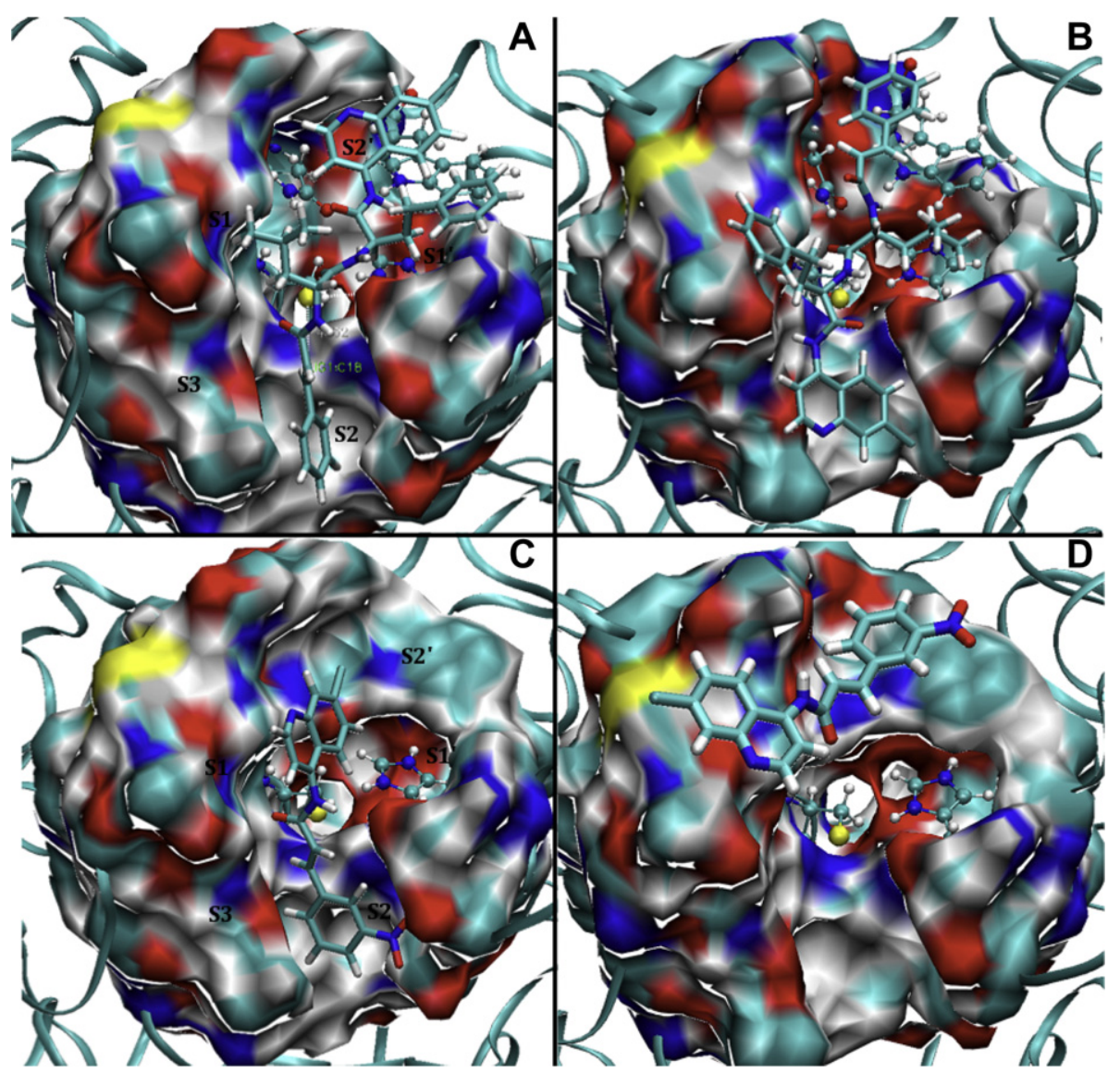

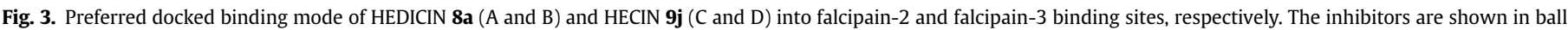
and stick representation while residues forming the "oxyanion hole" of parasitic cysteine proteases are in CPK representation. Enzyme subsites are shown on panels A and C. 
(Fig. 3B), which severely hinders an attack on the catalytic Cys thiolate. Similarly, the putative site of nucleophilic attack of HECINs 9 is placed far away from the catalytic Cys of FP3 (Fig. 3D). Indeed, the docked binding mode of molecule $\mathbf{9 j}$ is entirely outside the FP3 binding pocket, and this is probably because the area between the subsites is too narrow to accommodate two bulky (7-chloroquinolyl and cinnamoyl) groups so close to each other. The remaining test compounds displayed docking conformations in the FP3 active site similar to their respective analogs, which likely explains why none of the compounds inhibited FP3.

Computational results also suggested a preferred binding conformation for HEDICINs $\mathbf{8}$ into the FP2 binding site. All HEDICINs docked in an orientation similar to that previously found for $\mathbf{8 f}$ (Fig. S1B), by placing the 7-chloroquinolyl, homo-phenylalanyl, leucyl, and cinnamoyl groups into the $S 2^{\prime}, S 1^{\prime}, S 1$, and $S 2$ receptor subsites, respectively. Docking also suggested that, in general, the 7 -chloroquinoline ring of all HEDICINs established $\pi-\pi$ interactions with Trp206 and that its aromatic nitrogen formed a hydrogen bond with the backbone $-\mathrm{NH}$ of Gln36. The only exception to this binding mode was found for compound $\mathbf{8 c}$ that, due to the bulky para-isopropyl group in the aryl ring, was not able to dock into the FP2 catalytic site. No preferred docking conformation was evident for this molecule but, in all conformations, the cinnamoyl moiety was far away from the catalytic Cys. Thus, it was not surprising that compound $\mathbf{8 c}$ showed negligible activity against FP2. For all the other HEDICINs, the vinyl bond was placed within $\sim 4.5 \AA$ of the enzyme's Cys thiolate, suggesting that this large distance between the enzyme's nucleophile and the ligand's electrophile may explain the modest inhibitory activity shown by compounds 8 .

By analyzing the docked binding modes of all HECINs, we observed a preference for the positioning of the cinnamoyl group at the S2 cavity (Fig. 3C), except for compounds $\mathbf{9 c}$ and $\mathbf{9 i}$ (Fig. S2), which presented an upside-down orientation because their cinnamoyl groups could not fit into the S2 subsite. Despite the existence of two different binding conformations for this series, both orientations placed the ligand's vinyl group within 2.8-3.3 of the catalytic Cys thiolate, which could explain why HECINs were generally more active than HEDICINs as FP2 inhibitors (Table 1).

Another factor behind the overall better performance of HECINs 9 as FP2 inhibitors, as compared to HEDICINs 8, concerns the ability of compounds to establish strong non-covalent interactions within the enzyme's binding pocket. Indeed, after accommodation of any ligand into the falcipain catalytic site, the ligand will need to establish a minimum of contact points with the enzyme so it can remain tightly bound to it. In other words, a high ligand efficiency must be ensured, otherwise the ligand will leave the cavity spontaneously or upon competition with the natural substrate, even before it reacts with the catalytic Cys. The relevance of tight ligand-enzyme non-covalent interactions is consistent with the observation that two HECINs bearing a $\mathrm{NO}_{2}$ substituent $(\mathbf{9} \mathbf{i}-\mathbf{j})$ were active against FP2, whereas unsubstituted 9a was not. Indeed, comparing the stability of FP2 complexes with molecules 9a and 9j by molecular dynamics, we observed that after 500 ps the distance between the catalytic Cys and the putative site of nucleophilic attack of compound 9a increased to $\sim 6 \AA$ (Fig. S3), suggesting that the inhibitor left the binding site. In contrast, compound 9j had its double bond mainly within 3.5-4.0 A of the thiolate, suggesting that this molecule creates more contact points with the enzyme and, consequently, remains for a longer time in the binding site.

Both in vitro and in silico data suggest that smaller HECINs 9 constitute better templates than HEDICINs $\mathbf{8}$ for development of second-generation cinnamic acid/4-aminoquinoline conjugates as potential falcipain inhibitors. This conclusion is supported by comparative evaluation of HEDICIN and HECIN ligand efficiencies, as follows. Enzyme inhibitor candidates can be profiled regarding their ligand efficiencies by use of simple techniques, originally developed to provide a fast and simple way of assessing the quality of hits in high-throughput screening efforts [34]. As ligand efficiency is expectedly lower for smaller compounds, given the fewer contact points with the target enzyme, ligand size is a key parameter in calculating ligand quality [35]. Among current tools to rank ligand efficiencies is the Binding Efficiency Index (BEI), which divides the $\mathrm{pIC}_{50}$ (derived from $\mathrm{M}$ units) by the molecular weight (kDa units) of the compound [35]. This estimates how a ligand optimally binds a receptor relative to other ligands of any size. We have applied this methodology to compare the efficiency of HEDICINs 8 and HECINs 9 as falcipain ligands. BEI values ranged between 11.6 for $\mathbf{9 h}$ and 14.1 for $\mathbf{9 b}$, and between 7.2 for $\mathbf{8 g}$ to 8.1 for $\mathbf{8 a}$, consistent with the conclusion that HECINs 9 have higher falcipainbinding efficiencies than HEDICINs 8.

\subsubsection{Fukui indices of the vinyl carbons in HECINs}

As in all docked binding modes of HECINs $\mathbf{9}$, vinyl groups were in close proximity to the catalytic Cys (within 2.8-3.3 A of the thiolate), we investigated the influence of different aryl substituents on the electrophilic character of the HECINs' vinylic carbons. This study was based on the assumption that the vinyl bond would act as the Michael acceptor in the ligand's irreversible binding to the falcipain catalytic Cys. Atomic Fukui indices $(\mathbf{f}+)$, derived from Natural Bond Order (NBO) population analysis of the neutral compound and its respective cation [36], were used to quantify electrophilicity at particular atomic sites of the test compounds. Based on the rationale underlying this work, we considered only

\section{Table 2}

Calculated Fukui indices $(f+)$ used to predict the electrophilicity of atomic sites in HECINs 9. The value in brackets corresponds to the ratio between the $f+$ values of the most reactive vinyl carbon (highlighted in bold) and the other vinyl carbon. This can be used as a measure of the double bond activation. The $f+$ values in bold indicate the putative atomic site of nucleophilic attack for each inhibitor.

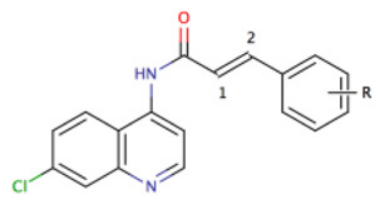

\begin{tabular}{|c|c|c|c|}
\hline Compound & $\mathrm{R}$ & Vinyl carbon & $f_{+}$ \\
\hline \multirow[t]{2}{*}{ 9a (2.12) } & $\mathrm{H}$ & 1 & 0.054 \\
\hline & & 2 & 0.114 \\
\hline \multirow[t]{2}{*}{$\mathbf{9 b}(2.35)$} & $p$-Me & 1 & 0.049 \\
\hline & & 2 & 0.114 \\
\hline \multirow[t]{2}{*}{$9 c(1.76)$} & $p-{ }^{i} \operatorname{Pr}$ & 1 & 0.055 \\
\hline & & 2 & 0.096 \\
\hline \multirow[t]{2}{*}{ 9d (2.75) } & $p$-OMe & 1 & 0.042 \\
\hline & & 2 & 0.116 \\
\hline \multirow[t]{2}{*}{$\mathbf{9 e}(1.73)$} & $m-\mathrm{F}$ & 1 & 0.069 \\
\hline & & 2 & 0.116 \\
\hline \multirow{2}{*}{ 9f (1.69) } & $p-\mathrm{F}$ & 1 & 0.069 \\
\hline & & 2 & 0.116 \\
\hline \multirow[t]{2}{*}{$\mathbf{9 g}(1.79)$} & $p-\mathrm{Cl}$ & 1 & 0.061 \\
\hline & & 2 & 0.110 \\
\hline \multirow[t]{2}{*}{ 9h (1.60) } & $p-\mathrm{Br}$ & 1 & 0.064 \\
\hline & & 2 & 0.102 \\
\hline \multirow[t]{2}{*}{ 9i (3.29) } & $o-\mathrm{NO}_{2}$ & 1 & 0.065 \\
\hline & & 2 & 0.020 \\
\hline \multirow[t]{2}{*}{$\mathbf{9 j}(2.25)$} & $m-\mathrm{NO}_{2}$ & 1 & 0.058 \\
\hline & & 2 & 0.026 \\
\hline \multirow[t]{2}{*}{$\mathbf{9 k}(2.48)$} & $p-\mathrm{NO}_{2}$ & 1 & 0.092 \\
\hline & & 2 & 0.037 \\
\hline
\end{tabular}


the two vinylic carbons in HECINs (atoms 1 and 2 in Table 2). The calculated Fukui indices showed that the greater the magnitude of $\mathrm{f}+$, the greater the change in electron density near the atoms of interest, and thus the higher reactivity of a molecule at that atomic site towards nucleophilic attack. Similarly, the ratio between the Fukui values of the two vinyl carbons was used as a measure of the activation, i.e., electron density imbalance in the double bond. Not surprisingly, the $\beta$-carbon of the $\alpha, \beta$-unsatured carbonyl moiety was the preferred site of nucleophilic attack (highlighted in bold, Table 2) for almost all HECINs $\mathbf{9}$ (Table 2). The only exceptions were for nitro derivatives $\mathbf{9 i}-\mathbf{k}$. This result likely arises from the high electron-withdrawing character of the nitro substituent, favoring electron delocalization towards the aryl instead of the carbonyl group. Also, we observed that compounds $\mathbf{9 i}-\mathbf{j}$ were among those with higher activation of the double bond (Fukui index ratios of 3.29 and 2.25 for $\mathbf{9 i}$ and $\mathbf{9 j}$, respectively) and also were among the most potent FP2 inhibitors in the HECIN series (Table 2). This is consistent with data for $\mathbf{9 b}$, which had the third highest $\mathrm{f}+(\mathrm{C} 2$ or $\mathrm{C} 1) / \mathrm{f}+(\mathrm{C} 1$ or $\mathrm{C} 2)$ ratio (2.35) and also the greatest inhibition of FP2 among HECINs (Table 1).

These data suggest that there is a threshold $\mathrm{f}+(\mathrm{C} 2) / \mathrm{f}+(\mathrm{C} 1)$ or $\mathrm{f}+(\mathrm{C} 1) / \mathrm{f}+(\mathrm{C} 2)$ ratio equal to 2 for HECINs, above which FP2 inhibition should be observed; 9a, 9d and 9k apparently escape this rule. Regarding compound $\mathbf{9 a}$, this fact can be ascribed to the lack of an adequate aryl substituent able to stabilize this ligand within the enzyme's ligand cavity, as previously shown by MD calculations (Fig. S3). Concerning molecules 9d and 9k, data suggest that bulky aryl substituents (9d, $p$-OMe and 9k, $p-\mathrm{NO}_{2}$ ) in the para position are unfavorable for activity possibly by establishing steric clashes with S2 subsite residues that eventually will compel the groups to leave the cavity. Of note, compound $\mathbf{9 j}\left(\mathrm{m}-\mathrm{NO}_{2}\right)$ accommodates into S2 cavity and remains within, as seen earlier by MD calculations (Fig. S3). This suggests that the aryl substituent could be slightly bulky in depth but not in length, which matches the limitation of S2 cavity as already proposed by a previous study [37].

In summary, we have found compounds able to inhibit hemozoin formation and/or FP2 activity, but data obtained do not allow establishing a correlation between these inhibitory capacities and compound's anti-plasmodial activity. In other words, results available do not allow establishing why HEDICINs 8 are active against blood-stage Plasmodium falciparum while HECINs $\mathbf{9}$ are completely devoid of such activity; likely explanations are that either HECINs are not efficiently uptaken by intra-erythrocytic parasites, and/or that HEDICINs exert their anti-plasmodial activities through a mechanism other than inhibition of hemozoin growth or of FP2 activity.

I. A higher uptake of HEDICINs $\mathbf{8}$, as compared to HECINs $\mathbf{9}$, could arise from:

a) a more efficient transport by passive diffusion, as HEDICINs are more lipophilic than HECINs; globally, HEDICINs and HECINs have similar acid-base properties (average estimated $p K a \sim 4$ for deprotonation of the quinolinic nitrogen), but differ by almost two units in their estimated $\log \mathrm{P}$ values $(4.2<\log \mathrm{P}<5.1$ for HECINs; $5.8<\log P<7.9$ for HEDICINs; cf. Table 1) [33], with the most lipophilic, 8c, being also the most active anti-plasmodial; amino acid and dipeptide esters are known to cross cell membranes by passive diffusion [38], so it is possible that the presence of the dipeptide spacer in HEDICINs augments cell permeation of these compounds by such process;

b) recognition of the dipeptide motif by specific transporters from the $P$. falciparum ABC transporter super-family, many of which have been taken as putative drug transporting proteins [39] and found to be directly implicated in drugresistance mechanisms [40,41];

c) increased permeability of dipeptide derivatives due to the new permeation pathways created in P. falciparum-infected RBCs to promote uptake of nutrients such as sugars or nucleosides [42], as well as amino acids and oligopeptides [31];

II. Alternatively, a difference in the respective mechanism of action (MOA) may be operating in addition, or in alternative, to a difference in uptake of HEDICINs versus HECINs:

a) due to their dipeptide moiety, HEDICINs might be able to inhibit plasmodial cytosolic proteases like aminopeptidases PfA-M1 and PfA-M17, which function in regulating the intracellular pool of amino acids required for parasite growth and development inside the red blood cell $[43,44]$;

b) HEDICINs anti-plasmodial activity could otherwise be related to the cinnamoyl moiety, as it has been shown that cinnamic acid derivatives inhibit the growth of intraerythrocytic $P$. falciparum in culture by inhibiting monocarboxylate (e.g. lactate) transport and translocation of other nutrients, as carbohydrates and amino acids required for parasite nourishment [45];

c) finally, HEDICINs anti-plasmodial activity could as well be due to inhibition of the new permeation pathways; meaning that HEDICINs could eventually block the new permeation pathways created in infected RBC (see above, I.c), hampering the uptake of molecules essential to the parasite; it is interesting to notice that amongst our most active molecules as antiplasmodials are those bearing a nitro-aryl moiety, also present in potent new permeation pathways inhibitors such as 5-nitro-2-(phenylalkylamino) benzoic acid derivatives [31].

\section{Concluding remarks}

The combined experimental and computational work undertaken, involving more than 20 novel compounds, led to the following observations.

1. Both families of compounds studied (HEDICINs 8 and HECINs 9 ) do not properly fit the narrow catalytic site of FP3.

2. HECINs $\mathbf{9}$ are better FP2 inhibitors than are HEDICINs $\mathbf{8}$, likely because the former are substantially smaller and have their vinyl bonds in closer vicinity to the FP2 catalytic Cys.

3. Among HECINs (9), the best FP2 inhibitors are those in which (a) the vinyl bond is activated, i.e., where the ratios between Fukui indices calculated for the two vinylic carbons are greater than 2, and (b) the aryl ring has a suitable substituent for the stabilization of the ligand-enzyme complex through noncovalent interactions.

4. Most HEDICINs $\mathbf{8}$ are able to block hemozoin formation in vitro, whereas HECINs 9 are not, which suggests that the spacer between the 4-aminoquinoline and the cinnamoyl moieties has a key role in mediating this activity.

5. Unlike HECINs (9), most HEDICINs (8) are active in vitro against blood-stage $P$. falciparum parasites, suggesting that the dipeptide spacer also has a key role in mediating this activity.

Overall, we can conclude that it is possible to create cinnamic acid/4-aminoquinoline conjugates with promising antimalarial and FP-inhibitory activities, at levels comparable to those of recently reported chalcone-based hybrids $[46,47]$. Such conjugates constitute promising leads for future development of novel antiplasmodials targeted at blood-stage malaria parasites. 


\section{Experimental section}

\subsection{Chemistry}

All solvents and common chemicals were from Sigma-Aldrich (Spain), whereas Boc-protected amino acids were from NovaBiochem (VWR International, Portugal) and the coupling agent TBTU was from Bachem (Switzerland). NMR spectra were acquired on a Bruker Avance III 400 spectrometer from solutions in either deuterated chloroform or deuterated dimethylsulfoxide (DMSO- $\mathrm{d}_{6}$ ) containing tetramethylsilane as internal reference. MS spectra were obtained on a Thermo Finnigan LCQ Deca XP Max LC/MS ${ }^{\mathrm{n}}$ instrument operating with electrospray ionization and ion-trap (ESI-IT) quadrupole detection. HPLC analyses were run for target compounds ( 8 and $\mathbf{9}$ ) using the following conditions: $30-100 \%$ of $B$ in $\mathrm{A}\left(\mathrm{A}=\mathrm{H}_{2} \mathrm{O}\right.$ with $0.05 \%$ of trifluoroacetic acid; $\mathrm{B}=$ acetonitrile $)$ in 22 min with a flow rate of $1 \mathrm{~mL} / \mathrm{min}$ on a Merck-Hitachi Lachrom Elite instrument equipped with a diode-array detector (DAD) and thermostated (Peltier effect) autosampler, using a Purospher STAR $\mathrm{RP}-18 \mathrm{e}$ column $(150 \times 4.0 \mathrm{~mm}$; particle size, $5 \mu \mathrm{M})$.

\subsection{General procedure for the synthesis of compounds $\mathbf{8 a}-\mathbf{d}, \mathbf{8 f}-\boldsymbol{l}$}

The relevant cinnamic acid (1.1 eq), PyBOP (1.1 eq), DIEA (2 eq.) and DCM $(2 \mathrm{~mL})$ were mixed in a round bottom flask and put under stirring for $20 \mathrm{~min}$. Then, a solution of 7 in DCM $(2 \mathrm{~mL})$ was added and the reaction allowed to proceed for three days. Precipitation was observed and the precipitate was collected by suction filtration, washed with ice-cold DCM, dried and identified as the pure target compound, except in the case of $\mathbf{8 1}$ ( $p$-nitrocinnamic acid derivative), which was further submitted to liquid chromatography on silica, using $\mathrm{DCM} / \mathrm{Me}_{2} \mathrm{CO} 6: 1(\mathrm{v} / \mathrm{v})$ as eluent. The synthesis details, analytical and spectroscopic data of intermediate compounds 3 to 7 and compound 10a are given in detail in SI.

In the particular case of compound 8e, derived from $p$-aminocinnamic acid, the $\mathrm{N}$-Boc-protected precursor of this cinnamic acid derivative was coupled to $\mathbf{7}$ as above described, and the resulting Boc-protected compound $\left(\mathbf{8 e}^{\prime}\right)$ was treated with neat TFA as described for the synthesis of $\mathbf{5}$ and $\mathbf{7}$ (see SI), to give the final unprotected compound, 8e. Analytical and spectroscopic data for $\mathbf{8} \mathbf{a}-\mathbf{l}$ and $\mathbf{8} \mathbf{e}^{\prime}$ are given below.

4.3. (R)-N-((R)-1-((7-chloroquinolin-4-yl)amino)-1-oxo-4phenylbutan-2-yl)-4-methyl-2-((E)-3-acrylamido)pentanamide (8a)

White solid (29.5 mg, 66\%); mp 241-245 ${ }^{\circ} \mathrm{C} ; R_{\mathrm{F}}\left(\mathrm{DCM} / \mathrm{Me}_{2} \mathrm{CO}\right.$ $6: 1) 0.36 ; \delta_{\mathrm{H}}\left(400 \mathrm{MHz}, \mathrm{DMSO}-\mathrm{d}_{6}\right) 10.36(\mathrm{~s}, 1 \mathrm{H}), 8.84(\mathrm{~d}, J=5.2 \mathrm{~Hz}$, $1 \mathrm{H}), 8.59(\mathrm{~d}, J=7.6 \mathrm{~Hz}, 1 \mathrm{H}), 8.34(\mathrm{~m}, 2 \mathrm{H}), 8.05(\mathrm{~m}, 2 \mathrm{H}), 7.67$ $(\mathrm{dd}, J=9.28 \mathrm{~Hz}, J=2 \mathrm{~Hz}, 1 \mathrm{H}), 7.56(\mathrm{~b}, 2 \mathrm{H}), 7.41(\mathrm{~m}, 4 \mathrm{H}), 7.24(\mathrm{~m}, 5 \mathrm{H})$; $6.79(\mathrm{~d}, J=15.6,1 \mathrm{H}) ; 4.69(\mathrm{~m}, 1 \mathrm{H}), 4.58(\mathrm{~m}, 1 \mathrm{H}), 2.71(\mathrm{~m}, 2 \mathrm{H}), 2.09$ $(\mathrm{m}, 2 \mathrm{H}), 1.66(\mathrm{~m}, 1 \mathrm{H}), 1.54(\mathrm{~m}, 2 \mathrm{H}), 0.90(\mathrm{~d}, J=16 \mathrm{~Hz}, J=6.4 \mathrm{~Hz}, 6 \mathrm{H})$; $\delta_{\mathrm{C}}\left(100 \mathrm{MHz}, \mathrm{DMSO}-\mathrm{d}_{6}\right) ; 172.7,171.8,164.9,152.2,149.1,141.5,141.1$, 139.0, 134.8, 134.2, 129.5, 128.9, 128.3, 128.3, 128.0, 127.5, 126.4, 125.9, 124.5, 121.9, 119.4, 112.4, 53.5, 51.1, 40.9, 33.0, 31.5, 24.2, 23.0, 21.6; ESI-IT MS: $m / z\left(\mathrm{M}+\mathrm{H}^{+}\right) 583.47\left(\mathrm{C}_{34} \mathrm{H}_{35} \mathrm{ClN}_{4} \mathrm{O}_{3}\right.$ requires 582.24); HPLC-DAD: $t_{\mathrm{r}}=12.4 \mathrm{~min}(\%$ area $=96 \%)$.

4.4. (R)-N-((R)-1-((7-chloroquinolin-4-yl)amino)-1-oxo-4phenylbutan-2-yl)-4-methyl-2-((E)-3-(4-tolyl)acrylamido) pentanamide $(\boldsymbol{8 b})$

White solid (30.1 mg, 76\%); mp 230-235 ${ }^{\circ} \mathrm{C} ; R_{\mathrm{F}}\left(\mathrm{DCM} / \mathrm{Me} \mathrm{CO}_{2} \mathrm{CO}\right.$ $6: 1) 0.24 ; \delta_{\mathrm{H}}\left(400 \mathrm{MHz}, \mathrm{DMSO}-\mathrm{d}_{6}\right) 10.35(\mathrm{~s}, 1 \mathrm{H}), 8.83$ (d. $J=5.2 \mathrm{~Hz}$, $1 \mathrm{H}), 8.55(\mathrm{~d}, J=7.6 \mathrm{~Hz}, 1 \mathrm{H}), 8.32(\mathrm{~m}, 2 \mathrm{H}), 8.05(\mathrm{~m}, 2 \mathrm{H}), 7.66$ (dd, $J=9 \mathrm{~Hz}, J=2 \mathrm{~Hz}, 1 \mathrm{H}), 7.42(\mathrm{~m}, 4 \mathrm{H}), 7.24(\mathrm{~m}, 6 \mathrm{H}), 6.75$ $(\mathrm{d}, J=16 \mathrm{~Hz}, 1 \mathrm{H}), 4.69(\mathrm{~m}, 1 \mathrm{H}), 4.57(\mathrm{~m}, 1 \mathrm{H}), 2.72(\mathrm{~m}, 2 \mathrm{H}), 2.32(\mathrm{~s}, 3 \mathrm{H})$, $2.10(\mathrm{~m}, 2 \mathrm{H}), 1.61(\mathrm{~m}, 3 \mathrm{H}), 0.90(\mathrm{~d}, J=16 \mathrm{~Hz}, J=6.4 \mathrm{~Hz}, 6 \mathrm{H}) ; \delta_{\mathrm{C}}$ (100 MHz, DMSO-d ${ }_{6}$ ) 172.7, 171.7, 165.0, 152.2, 149.0, 141.4, 141.0, $139.2,134.9,134.1,132.0,129.5,128.3,128.2,127.9,127.4,126.3,125.8$, 124.5, 120.8, 119.3, 112.4, 53.4, 51.6, 40.8, 32.9, 31.4, 24.8, 22.9, 21.6 20.9; ESI-IT MS: $m / z\left(\mathrm{M}+\mathrm{H}^{+}\right) 597.60\left(\mathrm{C}_{35} \mathrm{H}_{37} \mathrm{ClN}_{4} \mathrm{O}_{3}\right.$ requires 596.26); HPLC-DAD: $t_{\mathrm{r}}=18.3 \mathrm{~min}(\%$ area $=98 \%)$.

4.5. (R)-N-((R)-1-((7-chloroquinolin-4-yl)amino)-1-oxo-4phenylbutan-2-yl)-2-((E)-3-(4-iso-propylphenyl)acrylamido)-4methylpentanamide $(\mathbf{8 c})$

White solid (23 mg, 47\%); $\mathrm{mp} 238-240{ }^{\circ} \mathrm{C} ; R_{\mathrm{F}}\left(\mathrm{DCM} / \mathrm{Me}_{2} \mathrm{CO} 6: 1\right)$ $0.44 ; \delta_{\mathrm{H}}\left(400 \mathrm{MHz}, \mathrm{DMSO}-\mathrm{d}_{6}\right) 10.34(\mathrm{~s}, 1 \mathrm{H}), 8.83$ (d. $\left.J=5.2 \mathrm{~Hz}, 1 \mathrm{H}\right)$, $8.56(\mathrm{~d}, J=6.8 \mathrm{~Hz}, 1 \mathrm{H}), 8.31(\mathrm{~m}, 2 \mathrm{H}), 8.05(\mathrm{~m}, 2 \mathrm{H}), 7.67(\mathrm{~d}, J=8.8 \mathrm{~Hz}$, $1 \mathrm{H}), 7.42(\mathrm{~m}, 4 \mathrm{H}), 7.28(\mathrm{~m}, 6 \mathrm{H}), 6.73(\mathrm{~d}, J=16 \mathrm{~Hz}, 1 \mathrm{H}), 4.69(\mathrm{~m}, 2 \mathrm{H})$, $2.81(\mathrm{~m}, 3 \mathrm{H}), 2.09(\mathrm{~m}, 2 \mathrm{H}), 1.61(\mathrm{~m}, 3 \mathrm{H}), 1.20(\mathrm{~d}, J=6.8 \mathrm{~Hz}, 6 \mathrm{H}), 0.90$ $(\mathrm{dd}, J=16.6 \mathrm{~Hz}, J=6.4 \mathrm{~Hz}, 6 \mathrm{H}) ; \delta_{\mathrm{C}}\left(100 \mathrm{MHz}, \mathrm{DMSO}-\mathrm{d}_{6}\right) 172.7,171.7$, 165.0,152.1, 150.0, 149.0, 141.4, 141.0, 138.9, 134.1, 132.4,128.3,128.2, $127.9,127.5,126.8,126.3,125.8,124.5,120.9,119.36,112.4,53.4,51.0$ 40.8, 33.2, 33.0, 31.4, 24.8, 23.6, 22.9, 21.6; ESI-IT MS: $m / z\left(\mathrm{M}+\mathrm{H}^{+}\right)$ $625.36\left(\mathrm{C}_{37} \mathrm{H}_{41} \mathrm{ClN}_{4} \mathrm{O}_{3}\right.$ requires 624.29); HPLC-DAD: $t_{\mathrm{r}}=14.5 \mathrm{~min}$ (\% area $=93 \%)$

4.6. (R)-N-((R)-1-((7-chloroquinolin-4-yl)amino)-1-oxo-4phenylbutan-2-yl)-2-((E)-3-(4-methoxyphenyl)acrylamido)-4methylpentanamide (8d)

White solid (38 mg, 47\%); mp 223-241 ${ }^{\circ} \mathrm{C} ; R_{\mathrm{F}}\left(\mathrm{DCM} / \mathrm{Me}_{2} \mathrm{CO} 6: 1\right)$ 0.35; $\delta_{\mathrm{H}}\left(400 \mathrm{MHz}, \mathrm{DMSO}-\mathrm{d}_{6}\right) 10.34(\mathrm{~s}, 1 \mathrm{H}), 8.83(\mathrm{~d} . J=5.2 \mathrm{~Hz}, 1 \mathrm{H})$, $8.54(\mathrm{~d}, J=7.6 \mathrm{~Hz}, 1 \mathrm{H}), 8.32(\mathrm{~d}, J=8.8 \mathrm{~Hz}, 1 \mathrm{H}), 8.24(\mathrm{~d}, J=8 \mathrm{~Hz}, 1 \mathrm{H})$, $8.05(\mathrm{~m}, 2 \mathrm{H}), 7.66(\mathrm{~d}, J=9.2 \mathrm{~Hz}, J=2 \mathrm{~Hz}, 1 \mathrm{H}), 7.50(\mathrm{~d}, J=8.8 \mathrm{~Hz}, 2 \mathrm{H})$, $7.38(\mathrm{~d}, J=16 \mathrm{~Hz}, 1 \mathrm{H}), 7.25(\mathrm{~m}, 5 \mathrm{H}), 6.98(\mathrm{~d}, J=8.8 \mathrm{~Hz}, 2 \mathrm{H}), 6.63$ $(\mathrm{d}, J=15.6 \mathrm{~Hz}, 1 \mathrm{H}), 4.70(\mathrm{~m}, 1 \mathrm{H}), 4.56(\mathrm{~m}, 1 \mathrm{H}), 3.79(\mathrm{~s}, 3 \mathrm{H}), 2.72$ (m, 2H), $2.10(\mathrm{~m}, 2 \mathrm{H}), 1.61(\mathrm{~m}, 3 \mathrm{H}), 1.20(\mathrm{~d}, J=6.8 \mathrm{~Hz}, 6 \mathrm{H}), 0.90(\mathrm{dd}$, $J=16.8 \mathrm{~Hz}, J=6.4 \mathrm{~Hz}, 6 \mathrm{H}) ; \delta_{\mathrm{C}}(100 \mathrm{MHz}$, DMSO-d 6$) 172.8,171.7,165.2$, $160.3,152.1,149.0,141.4,141.0,138.7,134.1,129.0,128.7,128.2,127.9$, $127.3,126.3,125.8,124.5,119.4,114.3,112.4,55.2,53.4,51.0,40.8,33.0$, 31.4, 24.2, 22.9, 21.6; ESI-IT MS: $m / z\left(\mathrm{M}+\mathrm{H}^{+}\right) 613.73\left(\mathrm{C}_{35} \mathrm{H}_{37} \mathrm{ClN}_{4} \mathrm{O}_{4}\right.$ requires 612.25); HPLC-DAD: $t_{\mathrm{r}}=12.3 \mathrm{~min}(\%$ area $=91 \%)$.

4.7. tert-Butyl (4- $((E)-3-(((R)-1-(((R)-1-((7-c h l o r o q u i n o l i n-4-y l)$ amino)-1-oxo-4-phenylbutan-2-yl)amino)-4-methyl-1-oxopentan2-yl)amino)-3-oxoprop-1-en-1-yl)phenyl)carbamate (8 $\left.\boldsymbol{e}^{\prime}\right)$

Yellow solid (10 mg, $13 \%$ ); $\mathrm{mp}$ (dec.) $238^{\circ} \mathrm{C} ; R_{\mathrm{F}}\left(\mathrm{DCM} / \mathrm{Me}_{2} \mathrm{CO} 6: 1\right.$ ) $0.35 ; \delta_{\mathrm{H}}\left(400 \mathrm{MHz}, \mathrm{DMSO}_{-} \mathrm{d}_{6}\right) 10.33(\mathrm{~s}, 1 \mathrm{H}), 9.55(\mathrm{~s}, 1 \mathrm{H}), 8.83$ $(\mathrm{d}, J=4.8 \mathrm{~Hz}, 1 \mathrm{H}), 8.53(\mathrm{~d}, J=7.2 \mathrm{~Hz}, 1 \mathrm{H}), 8.32(\mathrm{~d}, J=9.2 \mathrm{~Hz}, 1 \mathrm{H}), 8.26$ $(\mathrm{d}, J=8 \mathrm{~Hz}, 1 \mathrm{H}), 8.05(\mathrm{~m}, 2 \mathrm{H}), 7.66(\mathrm{dd}, J=9.2 \mathrm{~Hz}, J=2 \mathrm{~Hz}, 1 \mathrm{H}), 7.47$ $(\mathrm{m}, 4 \mathrm{H}), 7.34(\mathrm{~d}, J=16 \mathrm{~Hz}, 1 \mathrm{H}), 7.23(\mathrm{~m}, 5 \mathrm{H}), 6.65(\mathrm{~d}, J=15.6 \mathrm{~Hz}, 1 \mathrm{H})$, $4.69(\mathrm{~m}, 1 \mathrm{H}), 4.55(\mathrm{~m}, 1 \mathrm{H}), 2.72(\mathrm{~m}, 2 \mathrm{H}), 2.08(\mathrm{~m}, 2 \mathrm{H}), 1.61(\mathrm{~m}, 3 \mathrm{H})$, $1.48(\mathrm{~s}, 9 \mathrm{H}), 0.90(\mathrm{dd}, J=17.2 \mathrm{~Hz}, J=6.4 \mathrm{~Hz}, 6 \mathrm{H}) ; \delta_{\mathrm{C}}(100 \mathrm{MHz}$, DMSO$\left.\mathrm{d}_{6}\right) 172.8,171.8,165.2,152.5,152.2,149.0,141.4,141.0,140.8,138.7$, 134.1, 128.5, 128.3, 128.2, 128.1, 127.1, 126.4, 125.9, 124.5, 119.7, 119.4, 118.0, 112.0, 79.3, 53.4, 51.1, 40.7, 33.0, 31.4, 28.0, 24.2, 22.9, 21.6; ESIIT MS: $m / z\left(\mathrm{M}+\mathrm{H}^{+}\right) 698.47\left(\mathrm{C}_{39} \mathrm{H}_{44} \mathrm{ClN}_{5} \mathrm{O}_{5}\right.$ requires 697.30); HPLCDAD: $t_{\mathrm{r}}=16.5 \min (\%$ area $=97 \%)$.

4.8. (R)-2-((E)-3-(4-Aminophenyl)acrylamido)-N-((R)-1-((7chloroquinolin-4-yl)amino)-1-oxo-4-phenylbutan-2-yl)-4methylpentanamide $(\mathbf{8 e})$

Yellow solid (12 mg, 78\%); $\mathrm{mp} 240-242{ }^{\circ} \mathrm{C} ; R_{\mathrm{F}}\left(\mathrm{DCM} / \mathrm{Me}_{2} \mathrm{CO} 6: 1\right)$ $0.11 ; \delta_{\mathrm{H}}\left(400 \mathrm{MHz}, \mathrm{DMSO}_{-} \mathrm{d}_{6}\right) 10.32(\mathrm{~s}, 1 \mathrm{H}), 8.83(\mathrm{~d}, J=5.2 \mathrm{~Hz}, 1 \mathrm{H})$, $8.49(\mathrm{~d}, J=7.6 \mathrm{~Hz}, 1 \mathrm{H}), 8.32(\mathrm{~d}, J=9.2 \mathrm{~Hz}, 1 \mathrm{H}), 8.08(\mathrm{~d}, J=8 \mathrm{~Hz}, 1 \mathrm{H})$, 
8.05 (m, 2H), $7.66(\mathrm{dd}, J=9 \mathrm{~Hz}, J=2 \mathrm{~Hz}, 1 \mathrm{H}), 7.23(\mathrm{~m}, 8 \mathrm{H}), 6.56$ $(\mathrm{d}, J=8.4 \mathrm{~Hz}, 2 \mathrm{H}), 6.43(\mathrm{~d}, J=16 \mathrm{z}, 1 \mathrm{H}), 5.57(\mathrm{~S}, 2 \mathrm{H}), 4.69(\mathrm{~m}, 1 \mathrm{H}), 4.52$ $(\mathrm{m}, 1 \mathrm{H}), 2.71(\mathrm{~m}, 2 \mathrm{H}), 2.08(\mathrm{~m}, 2 \mathrm{H}), 1.62(\mathrm{~m}, 3 \mathrm{H}), 0.90(\mathrm{dd}, J=18.4 \mathrm{~Hz}$, $J=6.4 \mathrm{~Hz}, 6 \mathrm{H}) ; \delta_{\mathrm{C}}\left(100 \mathrm{MHz}, \mathrm{DMSO}-\mathrm{d}_{6}\right) 172.9,171.8,165.9,152.1$, 150.5, 149.0, 141.4, 141.1,139.9, 134.1,129.0,128.3,128.2, 127.9, 126.4, 125.8, 124.5, 122.0, 119.4, 115.4, 113.6, 112.4, 53.4, 51.2, 40.7, 33.0, 31.4, 24.2, 22.9, 21.6; ESI-IT MS: $m / z\left(\mathrm{M}+\mathrm{H}^{+}\right) 598.30\left(\mathrm{C}_{34} \mathrm{H}_{36} \mathrm{ClN}_{5} \mathrm{O}_{3}\right.$ requires 597.25); HPLC-DAD: $t_{\mathrm{r}}=16.5 \mathrm{~min}(\%$ area $=97 \%$ ).

4.9. (R)-N-((R)-1-((7-chloroquinolin-4-yl)amino)-1-oxo-4phenylbutan-2-yl)-2-((E)-3-(3-fluorophenyl)acrylamido)-4methylpentanamide (8f)

White solid (28 mg, 56\%); mp 249-254 ${ }^{\circ} \mathrm{C} ; R_{\mathrm{F}}\left(\mathrm{DCM} / \mathrm{Me}_{2} \mathrm{CO} 6: 1\right)$ $0.35 ; \delta_{\mathrm{H}}\left(400 \mathrm{MHz}, \mathrm{DMSO}-\mathrm{d}_{6}\right) 10.36(\mathrm{~s}, 1 \mathrm{H}), 8.83(\mathrm{~d}, J=4.8 \mathrm{~Hz}, 1 \mathrm{H})$, $8.58(\mathrm{~d}, J=7.2 \mathrm{~Hz}, 1 \mathrm{H}), 8.34(\mathrm{~m}, 2 \mathrm{H}), 8.05(\mathrm{~m}, 2 \mathrm{H}), 7.67(\mathrm{~d}, J=9.2 \mathrm{~Hz}$, $J=2 \mathrm{~Hz} 1 \mathrm{H}), 7.43(\mathrm{~m}, 4 \mathrm{H}), 7.24(\mathrm{~m}, 6 \mathrm{H}), 6.83(\mathrm{~d}, J=16 \mathrm{~Hz}, 1 \mathrm{H}), 4.70$ (m, 1H), $4.59(\mathrm{~m}, 1 \mathrm{H}), 2.72(\mathrm{~m}, 2 \mathrm{H}), 2.09(\mathrm{~m}, 2 \mathrm{H}), 1.61(\mathrm{~m}, 3 \mathrm{H}), 0.90$ $(\mathrm{dd}, J=15.4 \mathrm{~Hz}, J=6.8 \mathrm{~Hz}, 6 \mathrm{H}) ; \delta_{\mathrm{C}}\left(100 \mathrm{MHz}, \mathrm{DMSO}^{-\mathrm{d}_{6}}\right) 172.6,171.7$, 164.5, 163.6, 161.1, 152.2, 149.0, 141.4, 141.0, 137.6, 137.4, 134.1, 130.9, $128.3,128.2,127.9,126.3,125.8,124.5,123.5,119.4,116.1,113.8,112.4$, 53.5, 51.1, 40.8, 33.0, 31.5, 24.2, 22.9, 21.6; ESI-IT MS: $m / z\left(\mathrm{M}+\mathrm{H}^{+}\right)$ $601.40\left(\mathrm{C}_{34} \mathrm{H}_{34} \mathrm{ClFN}_{4} \mathrm{O}_{3}\right.$ requires 600.23$)$; HPLC-DAD: $t_{\mathrm{r}}=11.2 \mathrm{~min}$ $(\%$ area $=100 \%)$.

4.10. (R)-N-((R)-1-((7-chloroquinolin-4-yl)amino)-1-oxo-4phenylbutan-2-yl)-2-((E)-3-(4-fluoro-phenyl)acrylamido)-4methylpentanamide (8g)

White solid (39 mg, 78\%); mp 246-249 ${ }^{\circ} \mathrm{C} ; R_{\mathrm{F}}\left(\mathrm{DCM} / \mathrm{Me}_{2} \mathrm{CO} 6: 1\right)$ $0.35 ; \delta_{\mathrm{H}}\left(400 \mathrm{MHz}, \mathrm{DMSO}-\mathrm{d}_{6}\right) 10.35(\mathrm{~s}, 1 \mathrm{H}), 8.83(\mathrm{~d}, J=5.2 \mathrm{~Hz}, 1 \mathrm{H})$, $8.56(\mathrm{~d}, J=7.2 \mathrm{~Hz}, 1 \mathrm{H}), 8.32(\mathrm{~d}, J=9.2 \mathrm{~Hz}, 2 \mathrm{H}), 8.05(\mathrm{~m}, 2 \mathrm{H}), 7.63$ $(\mathrm{m}, 3 \mathrm{H}), 7.44(\mathrm{~d}, J=15.6 \mathrm{~Hz}, 1 \mathrm{H}), 7.23(\mathrm{~m}, 7 \mathrm{H}), 6.73(\mathrm{~d}, J=15.6 \mathrm{~Hz}, 1 \mathrm{H})$, $4.69(\mathrm{~m}, 1 \mathrm{H}), 4.58(\mathrm{~m}, 1 \mathrm{H}), 2.72(\mathrm{~m}, 2 \mathrm{H}), 2.09(\mathrm{~m}, 2 \mathrm{H}), 1.61(\mathrm{~m}, 3 \mathrm{H}), 0.90$ $(\mathrm{dd}, J=16 \mathrm{~Hz}, J=6.4 \mathrm{~Hz}, 6 \mathrm{H}) ; \delta_{\mathrm{C}}\left(100 \mathrm{MHz}, \mathrm{DMSO}-\mathrm{d}_{6}\right) 172.7,171.7$, $164.8,152.2,149.0,141.4,141.0,137.8,134.1,131.4,129.6,128.3,128.2$, $127.9,126.3,125.8,124.5,121.8,119.4,116.0,115.7,112.4,53.5,51.0$, 40.8, 33.0, 31.5, 24.2, 22.9, 21.6; ESI-IT MS: $m / z\left(\mathrm{M}+\mathrm{H}^{+}\right) 601.47$ $\left(\mathrm{C}_{34} \mathrm{H}_{34} \mathrm{ClFN}_{4} \mathrm{O}_{3}\right.$ requires 600.23); HPLC-DAD: $t_{\mathrm{r}}=12.5 \mathrm{~min}$ (\% area $=85 \%$ ).

4.11. (R)-2-((E)-3-(4-Chlorophenyl)acrylamido)- $N-((R)-1-((7-$ chloroquinolin-4-yl)amino)-1-oxo-4-phenylbutan-2-yl)-4methylpentanamide (8h)

White solid (25 mg, 59\%); $\mathrm{mp} 249-260{ }^{\circ} \mathrm{C} ; R_{\mathrm{F}}\left(\mathrm{DCM} / \mathrm{Me}_{2} \mathrm{CO} 6: 1\right)$ $0.35 ; \delta_{\mathrm{H}}\left(400 \mathrm{MHz}, \mathrm{DMSO}-\mathrm{d}_{6}\right) 10.35(\mathrm{~s}, 1 \mathrm{H}), 8.83(\mathrm{~d}, J=4.8 \mathrm{~Hz}, 1 \mathrm{H})$, $8.57(\mathrm{~d}, J=7.6 \mathrm{~Hz}, 1 \mathrm{H}), 8.34(\mathrm{M}, 2 \mathrm{H}), 8.05(\mathrm{~m}, 2 \mathrm{H}), 7.66(\mathrm{dd}, J=9 \mathrm{~Hz}$, $J=2,1 \mathrm{H}), 7.58(\mathrm{~m}, 2 \mathrm{H}), 7.48(\mathrm{~m}, 2 \mathrm{H}), 7.42(\mathrm{~d}, J=16 \mathrm{~Hz}, 1 \mathrm{H}), 7.22$ $(\mathrm{m}, 5 \mathrm{H}), 6.79(\mathrm{~d}, J=15.6 \mathrm{~Hz}, 1 \mathrm{H}), 4.70(\mathrm{~m}, 1 \mathrm{H}), 4.58(\mathrm{~m}, 1 \mathrm{H}), 2.71$ $(\mathrm{m}, 2 \mathrm{H}), 2.09(\mathrm{~m}, 2 \mathrm{H}), 1.61(\mathrm{~m}, 3 \mathrm{H}), 0.90(\mathrm{dd}, J=16 \mathrm{~Hz}, J=6.4 \mathrm{~Hz}, 6 \mathrm{H})$; $\delta_{\mathrm{C}}\left(100 \mathrm{MHz}, \mathrm{DMSO}-\mathrm{d}_{6}\right) 172.6,171.7,164.7,152.2,149.0,141.4,141.0$, 137.6, 134.1, 133.8, 133.7, 129.1, 128.9, 128.3, 128.2, 127.9, 126.3, 125.8, 124.5, 122.7, 119.4, 112.4, 53.5, 51.1, 40.8, 33.0, 31.5, 24.2, 22.9, 21.6; ESI-IT MS: $m / z\left(\mathrm{M}+\mathrm{H}^{+}\right) 617.23\left(\mathrm{C}_{34} \mathrm{H}_{34} \mathrm{Cl}_{2} \mathrm{~N}_{4} \mathrm{O}_{3}\right.$ requires 616.20); HPLC-DAD: $t_{\mathrm{r}}=18.5 \mathrm{~min}(\%$ area $=100 \%)$.

4.12. (R)-2-((E)-3-(4-Bromophenyl)acrylamido)- $N-((R)-1-((7-$ chloroquinolin-4-yl)amino)-1-oxo-4-phenylbutan-2-yl)-4methylpentanamide (8i)

White solid (31 mg, 70\%); $\mathrm{mp} 240-246{ }^{\circ} \mathrm{C} ; R_{\mathrm{F}}\left(\mathrm{DCM} / \mathrm{Me}_{2} \mathrm{CO} 6: 1\right)$ $0.35 ; \delta_{\mathrm{H}}\left(400 \mathrm{MHz}, \mathrm{DMSO}-\mathrm{d}_{6}\right) 10.35(\mathrm{~s}, 1 \mathrm{H}), 8.83(\mathrm{~d}, J=4.8 \mathrm{~Hz}, 1 \mathrm{H})$, $8.57(\mathrm{~d}, J=7.2 \mathrm{~Hz}, 1 \mathrm{H}), 8.34(\mathrm{~m}, 2 \mathrm{H}), 8.05(\mathrm{~m}, 2 \mathrm{H}), 7.64(\mathrm{~m}, 3 \mathrm{H}), 7.51$ $(\mathrm{d}, J=8.4 \mathrm{~Hz}, 2 \mathrm{H}), 7.40(\mathrm{~d}, J=15.6 \mathrm{~Hz}, 1 \mathrm{H}), 7.24(\mathrm{~m}, 5 \mathrm{H}), 6.80$ $(\mathrm{d}, J=16 \mathrm{~Hz}, 1 \mathrm{H}), 4.69(\mathrm{~m}, 1 \mathrm{H}), 4.57(\mathrm{~m}, 1 \mathrm{H}), 2.71(\mathrm{~m}, 2 \mathrm{H}), 2.09(\mathrm{~m}$, $2 \mathrm{H}), 1.63(\mathrm{~m}, 3 \mathrm{H}), 0.90(\mathrm{dd}, J=16 \mathrm{~Hz}, J=6.4 \mathrm{~Hz}, 6 \mathrm{H}) ; \delta_{\mathrm{C}}(100 \mathrm{MHz}$, DMSO-d ${ }_{6}$ ) 172.6, 171.7, 164.6, 152.2, 149.0, 141.4, 141.0, 137.7, 134.1, $131.8,129.4,128.3,128.2,127.9,126.3,125.8,124.4,122.8,122.6,119.4$, 112.4, 53.4, 51.1, 40.8, 33.0, 31.4, 24.2, 22.9, 21.6; ESI-IT MS: $m / z$ $\left(\mathrm{M}+\mathrm{H}^{+}\right) 663.40\left(\mathrm{C}_{34} \mathrm{H}_{34} \mathrm{BrClN}_{4} \mathrm{O}_{3}\right.$ requires 660.15); HPLC-DAD: $t_{\mathrm{r}}=18.6 \min (\%$ area $=98 \%)$.

4.13. (R)-N-((R)-1-((7-chloroquinolin-4-yl)amino)-1-oxo-4phenylbutan-2-yl)-4-methyl-2-((E)-3-(2-nitrophenyl)acrylamido) pentanamide $(\mathbf{8 j})$

White solid (25 mg, 40\%); mp 260-265 ${ }^{\circ} \mathrm{C} ; R_{\mathrm{F}}\left(\mathrm{DCM} / \mathrm{Me}_{2} \mathrm{CO} 6: 1\right)$ $0.35 ; \delta_{\mathrm{H}}\left(400 \mathrm{MHz}, \mathrm{DMSO}-\mathrm{d}_{6}\right) 10.38(\mathrm{~s}, 1 \mathrm{H}), 8.83(\mathrm{~d}, J=5.2 \mathrm{~Hz}, 1 \mathrm{H})$, $8.62(\mathrm{~d}, J=6 \mathrm{~Hz}, 1 \mathrm{H}), 8.49(\mathrm{~d}, J=9.2 \mathrm{~Hz}, 1 \mathrm{H}), 8.32(\mathrm{~d}, J=7.2 \mathrm{~Hz}, 1 \mathrm{H})$, $8.05(\mathrm{~m}, 3 \mathrm{H}), 7.73(\mathrm{~m}, 5 \mathrm{H}), 7.25(\mathrm{~m}, 5 \mathrm{H}), 6.79(\mathrm{~d}, J=15.6 \mathrm{~Hz}, 1 \mathrm{H})$, $4.71(\mathrm{~m}, 1 \mathrm{H}), 4.60(\mathrm{~m}, 1 \mathrm{H}), 2.73(\mathrm{~m}, 2 \mathrm{H}), 2.10(\mathrm{~m}, 2 \mathrm{H}), 1.62(\mathrm{~m}, 3 \mathrm{H})$, $0.90(\mathrm{dd}, J=14.4 \mathrm{~Hz}, J=6.4 \mathrm{~Hz}, 6 \mathrm{H}) ; \delta_{\mathrm{C}}\left(100 \mathrm{MHz}, \mathrm{DMSO}-\mathrm{d}_{6}\right) 172.5$, $171.8,163.9,152.2,149.0,148.3,141.4,141.0,134.1,133.8,133.7,130.2$, 129.8, 128.5, 128.3, 128.2, 127.9, 126.6, 126.3, 125.8, 124.6, 124.5, $119.4,112.4,53.5,51.0,40.9,33.0,31.5,24.2,22.9,21.6$; ESI-IT MS: $m / z\left(\mathrm{M}+\mathrm{H}^{+}\right) 628.47\left(\mathrm{C}_{34} \mathrm{H}_{34} \mathrm{ClN}_{5} \mathrm{O}_{5}\right.$ requires 627.22); HPLC-DAD: $t_{\mathrm{r}}=17.8 \min (\%$ area $=98 \%)$.

4.14. (R)-N-((R)-1-((7-chloroquinolin-4-yl)amino)-1-oxo-4phenylbutan-2-yl)-4-methyl-2-((E)-3-(3-nitrophenyl)acrylamido) pentanamide $(\mathbf{8 k})$

White solid (26 mg, 50\%); $\mathrm{mp} 202-221^{\circ} \mathrm{C} ; R_{\mathrm{F}}\left(\mathrm{DCM} / \mathrm{Me}_{2} \mathrm{CO} 6: 1\right)$ $0.35 ; \delta_{\mathrm{H}}\left(400 \mathrm{MHz}, \mathrm{DMSO}-\mathrm{d}_{6}\right) 10.36(\mathrm{~s}, 1 \mathrm{H}), 8.83(\mathrm{~d}, J=4.8 \mathrm{~Hz}, 1 \mathrm{H})$, $8.60(\mathrm{~d}, J=7.2 \mathrm{~Hz}, 1 \mathrm{H}), 8.40(\mathrm{~m}, 2 \mathrm{H}), 8.33(\mathrm{~d}, J=8.8 \mathrm{~Hz}, 1 \mathrm{H}), 8.21$ (dd, $J=8.2 \mathrm{~Hz}, J=1.2 \mathrm{~Hz}, 1 \mathrm{H}), 8.05(\mathrm{~m}, 3 \mathrm{H}), 7.68(\mathrm{~m}, 2 \mathrm{H}), 7.56$ $(\mathrm{d}, J=15.6 \mathrm{~Hz}, 1 \mathrm{H}), 7.19(\mathrm{~m}, 5 \mathrm{H}), 6.99(\mathrm{~d}, J=16 \mathrm{~Hz}, 1 \mathrm{H}), 4.71(\mathrm{~m}, 1 \mathrm{H})$, $4.60(\mathrm{~m}, 1 \mathrm{H}), 2.71(\mathrm{~m}, 2 \mathrm{H}), 2.09(\mathrm{~m}, 2 \mathrm{H}), 1.62(\mathrm{~m}, 3 \mathrm{H}), 0.90(\mathrm{dd}$, $J=14.4 \mathrm{~Hz}, J=6.4 \mathrm{~Hz}, 6 \mathrm{H}) ; \delta_{\mathrm{C}}\left(100 \mathrm{MHz}, \mathrm{DMSO}-\mathrm{d}_{6}\right) 172.5,171.7$, $164.3,152.2,149.0,148.2,141.4,141.0,136.7,136.6,134.1,133.6$, 130.4, 128.3, 128.2, 127.9, 126.3, 125.9, 124.8, 124.5, 123.7, 121.4, 119.4, 112.4, 53.5, 51.1, 40.8, 33.0, 31.5, 24.2, 23.0, 21.6; ESI-IT MS: $m / z\left(\mathrm{M}+\mathrm{H}^{+}\right) 628.53\left(\mathrm{C}_{34} \mathrm{H}_{34} \mathrm{ClN}_{5} \mathrm{O}_{5}\right.$ requires 627.22); HPLC-DAD: $t_{\mathrm{r}}=11.1 \mathrm{~min}(\%$ area $=100 \%)$.

4.15. (R)-N-((R)-1-((7-chloroquinolin-4-yl)amino)-1-oxo-4phenylbutan-2-yl)-4-methyl-2-((E)-3-(4-nitrophenyl)acrylamido) pentanamide (8l)

Yellowish solid ( $11 \mathrm{mg}, 17 \%) ; \mathrm{mp} 252-257^{\circ} \mathrm{C} ; R_{\mathrm{F}}\left(\mathrm{DCM} / \mathrm{Me}_{2} \mathrm{CO}\right.$ 6:1) 0.35; $\delta_{\mathrm{H}}\left(400 \mathrm{MHz}, \mathrm{DMSO}-\mathrm{d}_{6}\right) 10.34(\mathrm{~s}, 1 \mathrm{H}), 8.82(\mathrm{~d}, J=5.2 \mathrm{~Hz}$, $1 \mathrm{H}), 8.54(\mathrm{~m}, 2 \mathrm{H}), 8.28(\mathrm{~m}, 2 \mathrm{H}), 8.04(\mathrm{~m}, 3 \mathrm{H}), 7.81(\mathrm{~m}, 2 \mathrm{H}), 7.66(\mathrm{dd}$, $J=9.2 \mathrm{~Hz}, J=2 \mathrm{~Hz}, 1 \mathrm{H}), 7.53(\mathrm{~d}, J=15.6,1 \mathrm{H}), 7.22(\mathrm{~m}, 5 \mathrm{H}), 6.96$ (d, $J=16 \mathrm{~Hz}, 1 \mathrm{H}), 4.69(\mathrm{~m}, 1 \mathrm{H}), 4.58(\mathrm{~m}, 1 \mathrm{H}), 2.72(\mathrm{~m}, 2 \mathrm{H}), 2.08$ $(\mathrm{m}, 2 \mathrm{H}), 1.60(\mathrm{~m}, 3 \mathrm{H}), 0.90(\mathrm{dd}, J=15.6 \mathrm{~Hz}, J=6.4 \mathrm{~Hz}, 6 \mathrm{H}) ; \delta_{\mathrm{C}}$ $(100 \mathrm{MHz}$, DMSO-d 6 ) 172.6, 171.8, 164.3, 152.3, 149.1, 147.6, 141.5, 141.4, 141.1, 136.8, 134.3, 128.6, 128.4, 128.3, 128.0, 126.5, 126.0, 124.6, 124.2, 122.8, 119.5, 112.6, 53.4, 51.2, 40.7, 33.0, 31.4, 24.2, 22.9, 21.6; ESI-IT MS: $m / z\left(\mathrm{M}+\mathrm{H}^{+}\right) 628.73\left(\mathrm{C}_{34} \mathrm{H}_{34} \mathrm{ClN}_{5} \mathrm{O}_{5}\right.$ requires 627.22); HPLC-DAD: $t_{\mathrm{r}}=18.0 \mathrm{~min}(\%$ area $=92 \%)$.

4.16. General procedure for the synthesis of compounds $\mathbf{9 a}-\boldsymbol{k}$

The relevant cinnamic acid (1.1 eq), PyBOP (1.1 eq), DIEA (2 eq.) and DCM $(2 \mathrm{~mL})$ were mixed in a round bottom flask and put under stirring for $20 \mathrm{~min}$. Then, a solution of $3(0.250 \mathrm{~g}, 1.40 \mathrm{mmol})$ in DMF $(2 \mathrm{~mL})$ was added and the reaction allowed to proceed for one day at room temperature. Following, the reaction mixture was diluted with $14 \mathrm{~mL}$ of DCM and sequentially washed with $1 \%$ aq. 
$\mathrm{HCl}(3 \times 18 \mathrm{~mL})$ and $5 \%$ aq. $\mathrm{Na}_{2} \mathrm{CO}_{3}(3 \times 18 \mathrm{~mL})$. Finally, the organic layer was dried with anhydrous $\mathrm{Na}_{2} \mathrm{SO}_{4}$, filtered, and evaporated to dryness In all cases, the crude product had to be purified by column liquid chromatography on silica, using $\mathrm{DCM} / \mathrm{Me}_{2} \mathrm{CO} 6: 1 \mathrm{v} / \mathrm{v}$ as eluent. Target compounds were isolated as solids, with analytical and spectral data given below.

\subsection{N-(7-chloroquinolin-4-yl)cinnamamide (9a)}

White solid (62 mg, 18\%); mp 170-176 ${ }^{\circ} \mathrm{C} ; R_{\mathrm{F}}\left(\mathrm{DCM} / \mathrm{Me}_{2} \mathrm{CO} 3: 1\right)$ 0.56; $\delta_{\mathrm{H}}\left(400 \mathrm{MHz}, \mathrm{DMSO}-\mathrm{d}_{6}\right) 10.42(\mathrm{~s}, 1 \mathrm{H}), 8.85(\mathrm{~d}, J=5.2 \mathrm{~Hz}, 1 \mathrm{H})$, $8.48(\mathrm{~d}, J=9.2 \mathrm{~Hz}, 1 \mathrm{H}), 8.33(\mathrm{~d}, J=5.2 \mathrm{~Hz}, 1 \mathrm{H}), 8.05(\mathrm{~d}, J=2.4 \mathrm{~Hz}$, $1 \mathrm{H}), 7.69(\mathrm{~m}, 4 \mathrm{H}), 7.47(\mathrm{~m}, 3 \mathrm{H}), 7.27(\mathrm{~d}, J=15.6 \mathrm{~Hz}, 1 \mathrm{H}) ; \delta_{\mathrm{C}}$ (100 MHz, DMSO-d ${ }_{6}$ ) 164.8, 152.2, 149.1, 141.9, 141.7, 134.5, 134.1, 130.1, 129.0, 128.0, 127.9, 126.3, 124.4, 121.5, 119.0, 111.5; ESI-IT MS: $m / z\left(\mathrm{M}+\mathrm{H}^{+}\right) 309.33\left(\mathrm{C}_{18} \mathrm{H}_{13} \mathrm{ClN}_{2} \mathrm{O}\right.$ requires 308.07); HPLC-DAD: $t_{\mathrm{r}}=8.10 \min (\%$ area $=85 \%)$.

\subsection{8. (E)-N-(7-chloroquinolin-4-yl)-3-(4-tolyl)acrylamide (9b)}

Beige solid (11 mg, 2\%); mp 209-218 ${ }^{\circ} \mathrm{C} ; R_{\mathrm{F}}\left(\mathrm{DCM} / \mathrm{Me}_{2} \mathrm{CO} 3: 1\right)$ 0.56; $\delta_{\mathrm{H}}\left(400 \mathrm{MHz}, \mathrm{DMSO}-\mathrm{d}_{6}\right) 10.38(\mathrm{~s}, 1 \mathrm{H}), 8.85(\mathrm{~d}, J=5.2 \mathrm{~Hz}, 1 \mathrm{H})$, $8.49(\mathrm{~d}, J=9.2 \mathrm{~Hz}, 1 \mathrm{H}), 8.33(\mathrm{~d}, J=5.2 \mathrm{~Hz}, 1 \mathrm{H}), 8.05(\mathrm{~d}, J=2 \mathrm{~Hz}, 1 \mathrm{H})$, $7.70(\mathrm{~m}, 2 \mathrm{H}), 7.58$ (d, $J=8.4 \mathrm{~Hz}, 2 \mathrm{H}), 7.29$ (d, $J=8 \mathrm{~Hz}, 2 \mathrm{H}), 7.21$ $(\mathrm{d}, J=15.6 \mathrm{~Hz}, 1 \mathrm{H}), 2.35(\mathrm{~s}, 3 \mathrm{H}) ; \delta_{\mathrm{C}}\left(100 \mathrm{MHz}, \mathrm{DMSO}-\mathrm{d}_{6}\right) 164.9,152.2$, 149.1, 141.9, 141.8, 140.0, 134.1, 131.8, 129.6, 128.0, 127.9, 126.3, 124.4, 120.4,119.0,111.5, 20.9; ESI-IT MS: $m / z\left(\mathrm{M}+\mathrm{H}^{+}\right) 323.40\left(\mathrm{C}_{19} \mathrm{H}_{15} \mathrm{ClN}_{2} \mathrm{O}\right.$ requires 322.09); HPLC-DAD: $t_{\mathrm{r}}=9.30 \mathrm{~min}(\%$ area $=85 \%$ ).

\subsection{9. (E)-N-(7-chloroquinolin-4-yl)-3-(4-isopropylphenyl)} acrylamide (9c)

Beige solid (17 mg, 3\%); mp 187-204 ${ }^{\circ} \mathrm{C} ; R_{\mathrm{F}}\left(\mathrm{DCM} / \mathrm{Me}_{2} \mathrm{CO} 3: 1\right)$ $0.56 ; \delta_{\mathrm{H}}\left(400 \mathrm{MHz}, \mathrm{DMSO}_{-} \mathrm{d}_{6}\right) 10.40(\mathrm{~s}, 1 \mathrm{H}), 8.84(\mathrm{~d}, J=5.2 \mathrm{~Hz}, 1 \mathrm{H})$, 8.49 (d, $J=9.2 \mathrm{~Hz}, 1 \mathrm{H}), 8.33(\mathrm{~d}, J=5.2 \mathrm{~Hz}, 1 \mathrm{H}), 8.05$ (d, $J=2.4 \mathrm{~Hz}$, $1 \mathrm{H}), 7.70(\mathrm{~m}, 2 \mathrm{H}), 7.61(\mathrm{~d}, J=8.4 \mathrm{~Hz}, 2 \mathrm{H}), 7.35(\mathrm{~d}, J=8 \mathrm{~Hz}, 2 \mathrm{H}), 7.23$ $(\mathrm{d}, J=15.6 \mathrm{~Hz}, 1 \mathrm{H}), 2.93(\mathrm{~s}, 1 \mathrm{H}), 1.22(\mathrm{~d}, J=6.8 \mathrm{~Hz}, 6 \mathrm{H}) ; \delta_{\mathrm{C}}(100 \mathrm{MHz}$, DMSO-d 6 ) 164.9, 152.2, 150.8, 149.1, 141.9, 141.8, 134.1, 132.1, 128.0, 127.0, 126.7, 126.3, 124.4, 120.8, 118.9, 111.5, 33.3, 23.5; ESI-IT MS: $m / z\left(\mathrm{M}+\mathrm{H}^{+}\right) 351.27\left(\mathrm{C}_{21} \mathrm{H}_{19} \mathrm{ClN}_{2} \mathrm{O}\right.$ requires 350.12); HPLC-DAD: $t_{\mathrm{r}}=11.4 \min (\%$ area $=85 \%)$.

\subsection{0. (E)-N-(7-chloroquinolin-4-yl)-3-(4-methoxyphenyl)} acrylamide (9d)

Beige solid (83 mg, 18\%); $\mathrm{mp} 240-242{ }^{\circ} \mathrm{C} ; R_{\mathrm{F}}\left(\mathrm{DCM} / \mathrm{Me}_{2} \mathrm{CO} 3: 1\right)$ $0.56 ; \delta_{\mathrm{H}}\left(400 \mathrm{MHz}, \mathrm{DMSO}_{\mathrm{d}}\right) 10.33(\mathrm{~s}, 1 \mathrm{H}), 8.83(\mathrm{~d}, J=4.8 \mathrm{~Hz}, 1 \mathrm{H})$, $8.49(\mathrm{~d}, J=8.8 \mathrm{~Hz}, 1 \mathrm{H}), 8.33(\mathrm{~d}, J=9.2 \mathrm{~Hz}, 1 \mathrm{H}), 8.05(\mathrm{~d}, J=2 \mathrm{~Hz}, 1 \mathrm{H})$, $7.67(\mathrm{~m}, 4 \mathrm{H}), 7.12(\mathrm{~d}, J=15.6 \mathrm{~Hz}, 1 \mathrm{H}), 7.04(\mathrm{~m}, 2 \mathrm{H}), 3.82(\mathrm{~s}, 3 \mathrm{H}) ; \delta_{\mathrm{C}}$ $\left(100 \mathrm{MHz}, \mathrm{DMSO}-\mathrm{d}_{6}\right)$ 165.1, 160.8, 152.2, 149.1, 141.9, 141.7, 134.0, 129.6, 127.9, 127.1, 126.2, 124.4, 118.9, 118.9, 114.5, 111.3, 55.3; ESI-IT MS: $m / z\left(\mathrm{M}+\mathrm{H}^{+}\right) 339.33\left(\mathrm{C}_{19} \mathrm{H}_{15} \mathrm{ClN}_{2} \mathrm{O}_{2}\right.$ requires 338.08); HPLCDAD: $t_{\mathrm{r}}=6.80 \mathrm{~min}(\%$ area $=97 \%)$.

\subsection{1. (E)-N-(7-chloroquinolin-4-yl)-3-(3-fluorophenyl)acrylamide(9e)}

Yellow solid (4 mg, $1 \%) ; \mathrm{mp} 181-190{ }^{\circ} \mathrm{C} ; R_{\mathrm{F}}\left(\mathrm{DCM} / \mathrm{Me}_{2} \mathrm{CO} 3: 1\right)$ 0.56; $\delta_{\mathrm{H}}\left(400 \mathrm{MHz}, \mathrm{DMSO}_{-} \mathrm{d}_{6}\right) 10.45(\mathrm{~s}, 1 \mathrm{H}), 8.85(\mathrm{~d}, J=5.2 \mathrm{~Hz}, 1 \mathrm{H})$, $8.47(\mathrm{~d}, J=8.8 \mathrm{~Hz}, 1 \mathrm{H}), 8.32(\mathrm{~d}, J=5.2 \mathrm{~Hz}, 1 \mathrm{H}), 8.06(\mathrm{dd}, J=2 \mathrm{~Hz}$, $1 \mathrm{H}), 7.71(\mathrm{~m}, 2 \mathrm{H}), 7.52(\mathrm{~m}, 3 \mathrm{H}), 7.29(\mathrm{~m}, 2 \mathrm{H}) ; \delta_{\mathrm{C}}\left(100 \mathrm{MHz}, \mathrm{DMSO}_{-} \mathrm{d}_{6}\right)$ 164.5, 163.6, 152.2, 149.1, 141.7, 140.5, 137.1, 134.1, 131.0, 128.0, 126.4, 124.3, 124.0, 123.1, 119.0, 116.6, 114.4, 111.6; ESI-IT MS: $m / z\left(\mathrm{M}+\mathrm{H}^{+}\right)$ $327.33\left(\mathrm{C}_{18} \mathrm{H}_{12} \mathrm{ClFN}_{2} \mathrm{O}\right.$ requires 326.06); HPLC-DAD: $t_{\mathrm{r}}=8.70 \mathrm{~min}$ (\% area $=98 \%)$.

\subsection{2. (E)-N-(7-chloroquinolin-4-yl)-3-(4-fluorophenyl) acrylamide (9f)}

White solid (19 mg, 4\%); mp 210-212 ${ }^{\circ} \mathrm{C} ; R_{\mathrm{F}}\left(\mathrm{DCM} / \mathrm{Me}_{2} \mathrm{CO} 3: 1\right)$ $0.56 ; \delta_{\mathrm{H}}(400 \mathrm{MHz}$, DMSO-d 6$) 10.42(\mathrm{~s}, 1 \mathrm{H}), 8.85(\mathrm{~d}, J=4.8 \mathrm{~Hz}, 1 \mathrm{H})$, $8.48(\mathrm{~d}, J=9.2 \mathrm{~Hz}, 1 \mathrm{H}), 8.32(\mathrm{~d}, J=4.8 \mathrm{~Hz}, 1 \mathrm{H}), 8.06(\mathrm{~d}, J=2 \mathrm{~Hz}, 1 \mathrm{H})$, $7.73(\mathrm{~m}, 4 \mathrm{H}), 7.33(\mathrm{~m}, 2 \mathrm{H}), 7.21(\mathrm{~d}, J=15.6 \mathrm{~Hz}, 1 \mathrm{H}) ; \delta_{\mathrm{C}}(100 \mathrm{MHz}$, DMSO-d 6 ) 164.7, 152.2, 149.1, 141.7, 140.7, 134.1, 131.2, 130.1, 128.0, 126.3, 124.4, 121.4, 119.0, 116.1, 115.9, 111.5; ESI-IT MS: $m / z\left(\mathrm{M}+\mathrm{H}^{+}\right)$ $327.11\left(\mathrm{C}_{18} \mathrm{H}_{12} \mathrm{ClFN}_{2} \mathrm{O}\right.$ requires 326.06); HPLC-DAD: $t_{\mathrm{r}}=8.50 \mathrm{~min}$ (\% area $=89 \%)$.

\subsection{3. (E)-3-(4-Chlorophenyl)-N-(7-chloroquinolin-4-yl)acrylamide (9g)}

White solid (44 mg, 21\%); $\mathrm{mp} 240-250{ }^{\circ} \mathrm{C} ; R_{\mathrm{F}}\left(\mathrm{DCM} / \mathrm{Me}_{2} \mathrm{CO} 3: 1\right)$ $0.56 ; \delta_{\mathrm{H}}\left(400 \mathrm{MHz}, \mathrm{DMSO}-\mathrm{d}_{6}\right) 10.44(\mathrm{~s}, 1 \mathrm{H}), 8.85(\mathrm{~d}, J=5.2 \mathrm{~Hz}, 1 \mathrm{H})$, $8.47(\mathrm{~d}, J=9.2 \mathrm{~Hz}, 1 \mathrm{H}), 8.32(\mathrm{~d}, J=4.8 \mathrm{~Hz}, 1 \mathrm{H}), 8.06(\mathrm{~d}, J=2 \mathrm{~Hz}, 1 \mathrm{H})$, $7.72(\mathrm{~m}, 4 \mathrm{H}), 7.55(\mathrm{~d}, J=8.4 \mathrm{~Hz}, 2 \mathrm{H}), 7.26(\mathrm{~d}, J=16 \mathrm{~Hz}, 1 \mathrm{H}) ; \delta_{\mathrm{c}}$ $(100 \mathrm{MHz}$, DMSO-d 6 ) 164.6, 152.2, 149.1, 141.7, 140.5, 134.5, 134.1, 133.5, 129.5, 129.1, 128.0, 126.3, 124.3, 122.3, 119.0, 111.6; ESI-IT MS: $m / z\left(\mathrm{M}+\mathrm{H}^{+}\right) 343.33\left(\mathrm{C}_{18} \mathrm{H}_{12} \mathrm{Cl}_{2} \mathrm{~N}_{2} \mathrm{O}\right.$ requires 342.03); HPLC-DAD: $t_{\mathrm{r}}=8.30 \mathrm{~min}(\%$ area $=96 \%)$.

\subsection{4. (E)-3-(4-Bromophenyl)-N-(7-chloroquinolin-4-yl)acrylamide(9h)}

Green solid (38 mg, 7\%); mp (dec.) $190{ }^{\circ} \mathrm{C} ; R_{\mathrm{F}}\left(\mathrm{DCM} / \mathrm{Me}_{2} \mathrm{CO} 3: 1\right.$ ) $0.56 ; \delta_{\mathrm{H}}\left(400 \mathrm{MHz}, \mathrm{DMSO}-\mathrm{d}_{6}\right) 10.44(\mathrm{~s}, 1 \mathrm{H}), 8.85(\mathrm{~d}, J=5.2 \mathrm{~Hz}, 1 \mathrm{H}), 8.47$ $(\mathrm{d}, J=8.8 \mathrm{~Hz}, 1 \mathrm{H}), 8.32(\mathrm{~d}, J=4.8 \mathrm{~Hz}, 1 \mathrm{H}), 8.08(\mathrm{~d}, J=2.4 \mathrm{~Hz}, 1 \mathrm{H}), 7.70$ $(\mathrm{m}, 6 \mathrm{H}), 7.27(\mathrm{~d}, J=16 \mathrm{~Hz}, 1 \mathrm{H}) ; \delta_{\mathrm{C}}\left(100 \mathrm{MHz}, \mathrm{DMSO}-\mathrm{d}_{6}\right) 164.6,152.2$, 149.1, 141.7, 140.5, 134.1, 133.8, 132.0, 129.8, 128.0, 126.3, 124.3, 123.3, 122.4, 118.9, 111.6; ESI-IT MS: $m / z\left(\mathrm{M}+\mathrm{H}^{+}\right) 387.27\left(\mathrm{C}_{18} \mathrm{H}_{12} \mathrm{BrClN}_{2} \mathrm{O}\right.$ requires 385.98); HPLC-DAD: $t_{\mathrm{r}}=8.60 \mathrm{~min}(\%$ area $=97 \%$ ).

\subsection{5. (E)-N-(7-chloroquinolin-4-yl)-3-(2-nitrophenyl)acrylamide (9i)}

Yellow solid (36 mg, 7\%); mp $168-200{ }^{\circ} \mathrm{C} ; R_{\mathrm{F}}\left(\mathrm{DCM} / \mathrm{Me}_{2} \mathrm{CO} 3: 1\right.$ ) $0.56 ; \delta_{\mathrm{H}}\left(400 \mathrm{MHz}, \mathrm{DMSO}-\mathrm{d}_{6}\right) 10.56(\mathrm{~s}, 1 \mathrm{H}), 8.87(\mathrm{~d}, J=5.2 \mathrm{~Hz}, 1 \mathrm{H}), 8.47$ $(\mathrm{d}, J=8.8 \mathrm{~Hz}, 1 \mathrm{H}), 8.32(\mathrm{~d}, J=4.8 \mathrm{~Hz}, 1 \mathrm{H}), 8.12(\mathrm{~d}, J=8 \mathrm{~Hz}, 1 \mathrm{H}), 8.07(\mathrm{~d}$, $J=2 \mathrm{~Hz}, 1 \mathrm{H}), 8.01(\mathrm{~d}, J=15.6 \mathrm{~Hz}, 1 \mathrm{H}), 7.87(\mathrm{~m}, 2 \mathrm{H}), 7.72(\mathrm{~m}, 3 \mathrm{H}), 7.25(\mathrm{~d}$, $J=15.6 \mathrm{~Hz}, 1 \mathrm{H}) ; \delta_{\mathrm{C}}\left(100 \mathrm{MHz}, \mathrm{DMSO}-\mathrm{d}_{6}\right) 163.9,152.2,149.0,148.2$, 141.4, 137.0, 134.1, 133.9, 130.7, 129.8, 128.8, 128.0, 126.4, 126.1, 124.8, 124.3, 119.0, 111.7; ESI-IT MS: $m / z\left(\mathrm{M}+\mathrm{H}^{+}\right) 354.33\left(\mathrm{C}_{18} \mathrm{H}_{12} \mathrm{ClN}_{3} \mathrm{O}_{3}\right.$ requires 353.06); HPLC-DAD: $t_{\mathrm{r}}=7.90 \mathrm{~min}(\%$ area $=97 \%)$.

\subsection{6. (E)-N-(7-chloroquinolin-4-yl)-3-(3-nitrophenyl)acrylamide (9j)}

White solid (11 mg, $2 \%$ ); $\mathrm{mp}$ (dec.) $240-247^{\circ} \mathrm{C} ; R_{\mathrm{F}}\left(\mathrm{DCM} / \mathrm{Me}_{2} \mathrm{CO}\right.$ 3:1) 0.56; $\delta_{\mathrm{H}}\left(400 \mathrm{MHz}, \mathrm{DMSO}-\mathrm{d}_{6}\right) 10.49(\mathrm{~s}, 1 \mathrm{H}), 8.86(\mathrm{~d}, J=4.8 \mathrm{~Hz}$, $1 \mathrm{H}), 8.53$ (d, $J=2 \mathrm{~Hz}, 2 \mathrm{H}), 8.34$ (d, $J=5.2 \mathrm{~Hz}, 1 \mathrm{H}), 8.27$ (dd, $J=8.2 \mathrm{~Hz}, J=1.2 \mathrm{~Hz}, 1 \mathrm{H}), 8.11(\mathrm{~d}, J=8 \mathrm{~Hz}, 1 \mathrm{H}), 8.07(\mathrm{~d}, J=2 \mathrm{~Hz}, 1 \mathrm{H})$, $7.84(\mathrm{~d}, J=16 \mathrm{~Hz}, 1 \mathrm{H}), 7.76(\mathrm{~m}, 2 \mathrm{H}), 7.46(\mathrm{~d}, J=16 \mathrm{~Hz}, 1 \mathrm{H}) ; \delta_{\mathrm{c}}$ (100 MHz, DMSO-d 6 ) 164.2, 152.2, 149.1, 148.2, 141.5, 139.4, 136.3, 134.5, 134.2, 130.6, 128.0, 126.4, 124.4, 124.3, 121.5, 118.9, 111.5; ESIIT MS: $m / z\left(\mathrm{M}+\mathrm{H}^{+}\right) 354.53\left(\mathrm{C}_{18} \mathrm{H}_{12} \mathrm{ClN}_{3} \mathrm{O}_{3}\right.$ requires 353.06); HPLCDAD: $t_{\mathrm{r}}=7.20 \min (\%$ area $=100 \%)$.

\subsection{7. (E)-N-(7-chloroquinolin-4-yl)-3-(4-nitrophenyl)acrylamide} (9k)

Beige solid (9 mg, 5\%); mp desc. $205{ }^{\circ} \mathrm{C} ; R_{\mathrm{F}}\left(\mathrm{DCM} / \mathrm{Me}_{2} \mathrm{CO} 3: 1\right)$ 0.56; $\delta_{\mathrm{H}}\left(400 \mathrm{MHz}, \mathrm{DMSO}-\mathrm{d}_{6}\right) 10.58(\mathrm{~s}, 1 \mathrm{H}), 8.87(\mathrm{~d}, J=5.2 \mathrm{~Hz}, 1 \mathrm{H})$, $8.48(\mathrm{~d}, J=9.2 \mathrm{~Hz}, 1 \mathrm{H}), 8.33(\mathrm{~m}, 3 \mathrm{H}), 8.07(\mathrm{~d}, J=2.4 \mathrm{~Hz}, 1 \mathrm{H}), 7.94(\mathrm{~d}$, $J=8.8 \mathrm{~Hz}, 2 \mathrm{H}), 7.83(\mathrm{~d}, J=16 \mathrm{~Hz}, 1 \mathrm{H}), 7.74(\mathrm{dd}, J=9 \mathrm{~Hz}, J=2 \mathrm{~Hz}, 1 \mathrm{H})$, $7.44(\mathrm{~d}, J=15.6 \mathrm{~Hz}, 1 \mathrm{H}) ; \delta_{\mathrm{C}}\left(100 \mathrm{MHz}, \mathrm{DMSO}-\mathrm{d}_{6}\right) 164.1,152.2,149.1$, $147.8,141.5,141.0,139.3,134.2,128.9,128.0,126.4,125.8,124.3$, 
124.2, 119.0, 111.7; ESI-IT MS: $m / z\left(\mathrm{M}+\mathrm{H}^{+}\right) 354.27\left(\mathrm{C}_{18} \mathrm{H}_{12} \mathrm{ClN}_{3} \mathrm{O}_{3}\right.$ requires 353.06); HPLC-DAD: $t_{\mathrm{r}}=7.20 \mathrm{~min}(\%$ area $=92 \%)$.

\subsection{In vitro assays}

\subsubsection{Inhibition of heme polymerization}

The heme polymerization assay was performed as previously described $[28,29]$. Briefly, different concentrations $(0.1-1 \mathrm{mM})$ of test compounds dissolved in DMSO were added in triplicate to $50 \mu \mathrm{L}$ hemin chloride dissolved in DMSO $(5.2 \mathrm{mg} / \mathrm{mL})$. Controls contained equal volumes of water (or DMSO. $\beta$-hematin formation was initiated by the addition of acetate buffer $0.2 \mathrm{M}(100 \mu \mathrm{L}, \mathrm{pH}$ 4.4), plates were incubated at $37{ }^{\circ} \mathrm{C}$ for $48 \mathrm{~h}$ and they were centrifuged at $3000 \mathrm{rpm}$ for $15 \mathrm{~min}$ (SIGMA 3-30K). After discarding the supernatant, the pellet was washed four times with DMSO $(200 \mu \mathrm{L})$, and finally dissolved in $0.2 \mathrm{M}$ aq. $\mathrm{NaOH}(200 \mu \mathrm{L})$. The solubilized aggregates were further diluted 1:6 with $0.1 \mathrm{M}$ aq. $\mathrm{NaOH}$ and absorbances recorded at $405 \mathrm{~nm}$ Biotek Powerwave XS with software Gen5 1.07).

\subsubsection{Antiplasmodial activity assays}

The activity of compounds against cultured $P$. falciparum was evaluated as previously reported [48]. Briefly, synchronized ringstage W2 strain parasites were cultured with multiple concentrations of test compounds (added from $1000 \times$ stocks in DMSO) in RPMI 1640 medium with $10 \%$ human serum or $0.5 \%$ Albumax serum substitute. After a $48 \mathrm{~h}$ incubation, when control cultures contained new rings, parasites were fixed with $1 \%$ formaldehyde in PBS, pH 7.4, for $48 \mathrm{~h}$ at room temperature and then labeled with YOYO-1 ( $1 \mathrm{nM}$; Molecular Probes) in $0.1 \%$ Triton X-100 in PBS. Parasitemias were determined from dot plots (forward scatter vs. fluorescence) acquired on a FACSort flow cytometer using CELLQUEST software (Becton Dickinson). $\mathrm{IC}_{50}$ s for growth inhibition were determined with GraphPad Prism software from plots of percentages of the control parasitemia relative to inhibitor concentration. In each case, goodness of curve fit was documented by $R^{2}$ values of $>0.95$.

\subsubsection{FP inhibition assays}

Recombinant FP2 and FP3 were expressed as previously described $[49,50]$ and assays of inhibition of the enzymes were performed as previously reported [9]. In brief, equal amounts (1 nM) of recombinant FP2 and FP3 were incubated with different concentrations of test compounds (added from $10 \mathrm{mM}$ stocks in DMSO) in $100 \mathrm{mM}$ sodium acetate, $\mathrm{pH}$ 5.5, $10 \mathrm{mM}$ dithiothreitol for $30 \mathrm{~min}$ at room temperature before addition of the substrate benzoxycarbonyl-Leu-Arg-7-amino-4-methyl-coumarin (final concentration $25 \mu \mathrm{M}$ ). Fluorescence was continuously monitored for 30 min at room temperature in a Labsystems Fluoroskan II spectrofluorometer and IC50s were determined from plots of activity over enzyme concentration with GraphPad Prism software.

\subsection{In silico studies}

\subsubsection{Docking of inhibitors}

Docking was performed with GOLD [51] version 5.0.1, allowing full flexibility for the ligand while keeping the protein fixed. The Xray structure of FP2 and FP3 (PDB code: 3BPF [7] and 3BWK [16], respectively) were used and prepared for docking. The original ligand, ions and solvent molecules were removed and the proteins were protonated using the $\mathrm{H}++$ server [52] assuming a $\mathrm{pH}$ of 5.5 and a salinity of $0.15 \mathrm{~mol} / \mathrm{L}$. The proteins were then minimized with the AMBER program [53] by 500 steps of steepest descent followed by 2000 steps of conjugate gradient to remove bad contacts using a generalized-Born solvent model. The biomolecular force field ff03 [54] was used. The docking exploration consisted of 500 independent runs of the docking algorithm with each compound, using the default genetic algorithm (GA) search parameters and the GoldScore scoring function. The automated assignment of protein and ligand atom types was checked to ensure a correct treatment of the potential hydrogen bond donors and acceptors. The binding site was defined as 15 Å radius from the catalytic amino acid Cys42 and Cys51 for FP2 and FP3, respectively. Previously, the docking protocol was tested to verify if GOLD was able to reproduce the experimental conformation of the ligands bound to the enzymes.

\subsubsection{Molecular dynamics simulations}

A topological file and a coordinate set was prepared for each complex using the leap module of AMBER 10 with the ff03 and GAFF [55] force field parameters for the protein and ligands, respectively. Partial atomic charges were determined with the restrained electrostatic potential (RESP) [56], after $a b$ initio calculations using the Gaussian 03 [57] software at the HF/6-31G(d) level, and then were assigned to atoms using the Antechamber module. Each complex was solvated by placing a periodic box of TIP3P water up to a distance of $8 \AA$ from the protein and the system was neutralized by adding $\mathrm{Na}^{+}$ions. After a careful equilibration of the water box, the full system was gently heated through six 5 ps molecular dynamic (MD) runs where backbone restraints were gradually reduced from 10 to $5 \mathrm{kcal} / \mathrm{mol}$, while the temperature was raised from 0 to $300 \mathrm{~K}$. The heating was followed by a $100 \mathrm{ps}$ run in NVT ensemble and four 100 ps runs in NpT ensemble where backbone restraints will be gradually reduced from 5 to $1 \mathrm{kcal} / \mathrm{mol}$. After minimization, a subsequent 3 ns production run (NpT conditions) was performed.

\subsubsection{Fukui indices}

To obtain some information about the favored position for the nucleophilic attack of the catalytic thiolate over the double bond of the compounds, the local Fukui indices were calculated according to Eq. (1):

$f_{\mathrm{A}}^{+}=P_{\mathrm{A}}(N+1)-P_{\mathrm{A}}(N)$

where $f_{A}^{+}$stands for the electrophilicity of atom $A$ in a molecule and $\mathrm{P}$ for the population of atom A in a molecule with $N$ or $N+1$ electrons. The populations for the neutral $(N+1)$ and cationic $(N)$ species were obtained from Natural Bond Order (NBO) population analysis [58] for the optimized structures of the compounds in the gaseous phase. The calculations considered the hybrid density functional B3LYP $[59,60]$ approach and the $6-31+\mathrm{G}(\mathrm{d})$ basis set as included in the Gaussian 03 suite [57], taking as starting structures the docked configurations.

\section{Acknowledgments}

This work was mainly supported by Fundação para a Ciência e a Tecnologia (FCT, Portugal) through projects PTDC/QUI/65142/ 2006 and PTDC/QUI-QUI/116864/2010 coordinated by PG, and through strategic projects PEst-C/QUI/UI0081/2011 and PEst-C/ CTM/LA0011/2011 awarded to CIQUP and CICECO, respectively. Thanks are due to FCT also for both the LC-MS and NMR facilities, respectively funded through projects CONC-REEQ/275/QUI and REDE/1517/RMN/2005. CT thanks FCT for post-doctoral grant SFRH/ BPD/62967/2009. JRBG is a holder of a Ciência 2007 position of the Portuguese Ministry of Science. PJR is a Distinguished Clinical Scientist of the Doris Duke Charitable Foundation.

\section{Appendix A. Supplementary information}

Supplementary data related to this article can be found online at doi:10.1016/j.ejmech.2012.05.022. 


\section{References}

[1] R. Batista, J. Silva Ade Jr., A.B. de Oliveira, Plant-derived antimalarial agents: new leads and efficient phytomedicines. Part II. Non-alkaloidal natural products, Molecules 14 (2009) 3037-3072.

[2] P.J. Rosenthal, Antimalarial Chemotherapy: Mechanisms of Action, Resistance, and New Directions in Drug Discovery, Humana Press Inc., New Jersey, 2001.

[3] C. Teixeira, J.R. Gomes, P. Gomes, Falcipains, Plasmodium falciparum cysteine proteases as key drug targets against malaria, Curr. Med. Chem. 18 (2011) 1555-1572.

[4] S. Jana, J. Paliwal, Novel molecular targets for antimalarial chemotherapy, Int. J. Antimicrob. Agents 30 (2007) 4-10.

[5] G. Padmanaban, Drug targets in malaria parasites, Adv. Biochem. Eng. Biotechnol. 84 (2003) 123-141.

[6] G. Padmanaban, V.A. Nagaraj, P.N. Rangarajan, Drugs and drug targets. against. malaria, Curr. Sci. India 92 (2007) 1545-1555.

[7] I.D. Kerr, J.H. Lee, K.C. Pandey, A. Harrison, M. Sajid, P.J. Rosenthal, L.S. Brinen, Structures of falcipain-2 and falcipain-3 bound to small molecule inhibitors: implications for substrate specificity, J. Med. Chem. 52 (2009) 852-857.

[8] S. Kumar, M. Guha, V. Choubey, P. Maity, U. Bandyopadhyay, Antimalarial drugs inhibiting hemozoin (beta-hematin) formation: a mechanistic update, Life Sci. 80 (2007) 813-828.

[9] B.R. Shenai, B.J. Lee, A. Alvarez-Hernandez, P.Y. Chong, C.D. Emal, R.J. Neitz, W.R. Roush, P.J. Rosenthal, Structure-activity relationships for inhibition of cysteine protease activity and development of Plasmodium falciparum by peptidyl vinyl sulfones, Antimicrob. Agents Chemother. 47 (2003) 154-160.

[10] I. Weissbuch, L. Leiserowitz, Interplay between malaria, crystalline hemozoin formation, and antimalarial drug action and design, Chem. Rev. 108 (2008) 4899-4914.

[11] F.W. Muregi, A. Ishih, Next-generation antimalarial drugs: hybrid molecules as a new strategy in drug design, Drug Dev. Res. 71 (2010) 20-32.

[12] S.R. Vippagunta, A. Dorn, H. Matile, A.K. Bhattacharjee, J.M. Karle, W.Y. Ellis, R.G. Ridley, J.L. Vennerstrom, Structural specificity of chloroquine-hematin binding related to inhibition of hematin polymerization and parasite growth, J. Med. Chem. 42 (1999) 4630-4639.

[13] V.K. Zishiri, M.C. Joshi, R. Hunter, K. Chibale, P.J. Smith, R.L. Summers, R.E. Martin, T.J. Egan, Quinoline antimalarials containing a Dibemethin group are active against Chloroquinone-resistant Plasmodium falciparum and inhibit chloroquine transport via the $P$. falciparum chloroquine-resistance transporter (PfCRT), J. Med. Chem. 54 (2011) 6956-6968.

[14] J. Wiesner, A. Mitsch, P. Wissner, H. Jomaa, M. Schlitzer, Structure-activity relationships of novel anti-malarial agents. Part 2: cinnamic acid derivatives, Bioorg. Med. Chem. Lett. 11 (2001) 423-424.

[15] Y. Kouassi, L.A. Shelef, Inhibition of Lysteria monocytogenes by cinnamic acid: possible interaction of the acid with cysteinyl residues, J. Food Saf. 18 (1998) 231-242.

[16] I.D. Kerr, J.H. Lee, C.J. Farady, R. Marion, M. Rickert, M. Sajid, K.C. Pandey, C.R. Caffrey, J. Legac, E. Hansell, J.H. McKerrow, C.S. Craik, P.J. Rosenthal, L.S. Brinen, Vinyl sulfones as antiparasitic agents and a structural basis for drug design, J. Biol. Chem. 284 (2009) 25697-25703.

[17] M.M. Santos, R. Moreira, Michael acceptors as cysteine protease inhibitors, Mini Rev. Med. Chem. 7 (2007) 1040-1050.

[18] P.J. Rosenthal, J.E. Olson, G.K. Lee, J.T. Palmer, J.L. Klaus, D. Rasnick, Antimalarial effects of vinyl sulfone cysteine proteinase inhibitors, Antimicrob. Agents Chemother. 40 (1996) 1600-1603.

[19] R. Capela, R. Oliveira, L.M. Goncalves, A. Domingos, J. Gut, P.J. Rosenthal, F. Lopes, R. Moreira, Artemisinin-dipeptidyl vinyl sulfone hybrid molecules: design, synthesis and preliminary SAR for antiplasmodial activity and falcipain-2 inhibition, Bioorg. Med. Chem. Lett. 19 (2009) 3229-3232.

[20] E. Verissimo, N. Berry, P. Gibbons, M.L. Cristiano, P.J. Rosenthal, J. Gut, S.A. Ward, P.M. O'Neill, Design and synthesis of novel 2-pyridone peptidomimetic falcipain 2/3 inhibitors, Bioorg. Med. Chem. Lett. 18 (2008) 4210-4214.

[21] C. Adessi, C. Soto, Converting a peptide into a drug: strategies to improve stability and bioavailability, Curr. Med. Chem. 9 (2002) 963-978.

[22] M. Ali, N. Manolios, Peptide delivery systems, Lett. Pept. Sci. 8 (2001) $289-294$.

[23] F. Costa, I.F. Carvalho, R.C. Montelaro, P. Gomes, M.C. Martins, Covalent immobilization of antimicrobial peptides (AMPs) onto biomaterial surfaces, Acta Biomater. 7 (2011) 1431-1440.

[24] F. Gaston, G.C. Granados, S. Madurga, F. Rabanal, F. Lakhdar-Ghazal, E. Giralt, E. Bahraoui, Development and characterization of peptidic fusion inhibitors derived from HIV-1 gp41 with partial D-amino acid substitutions, ChemMedChem 4 (2009) 570-581.

[25] R.B. Merrifield, P. Juvvadi, D. Andreu, J. Ubach, A. Boman, H.G. Boman, Retro and retroenantio analogs of cecropin-melittin hybrids, Proc. Natl. Acad. Sci. U S A 92 (1995) 3449-3453.

[26] C.A.G.N. Montalbetti, V. Falque, Amide bond formation and peptide coupling, Tetrahedron 61 (2005) 10827-10852.

[27] S.-Y. Han, Y.-A. Kim, Recent development of peptide coupling reagents in organic synthesis, Tetrahedron 60 (2004) 2447-2467.

[28] R. Baelmans, E. Deharo, V. Munoz, M. Sauvain, H. Ginsburg, Experimental conditions for testing the inhibitory activity of chloroquine on the formation of beta-hematin, Exp. Parasitol. 96 (2000) 243-248.
[29] A. Barazarte, G. Lobo, N. Gamboa, J.R. Rodrigues, M.V. Capparelli, A. AlvarezLarena, S.E. Lopez, J.E. Charris, Synthesis and antimalarial activity of pyrazolo and pyrimido benzothiazine dioxide derivatives, Eur. J. Med. Chem. 44 (2009) 1303-1310.

[30] N. Vale, M. Prudencio, C.A. Marques, M.S. Collins, J. Gut, F. Nogueira, J. Matos, P.J. Rosenthal, M.T. Cushion, V.E. do Rosario, M.M. Mota, R. Moreira, P. Gomes, Imidazoquines as antimalarial and antipneumocystis agents, J. Med. Chem. 52 (2009) 7800-7807.

[31] K. Kirk, Membrane transport in the malaria-infected erythrocyte, Physiol. Rev. 81 (2001) 495-537.

[32] H.M. Staines, C. Rae, K. Kirk, Increased permeability of the malaria-infected erythrocyte to organic cations, Biochim. Biophys. Acta 1463 (2000) 88-98.

[33] MarvinSketch 5.2.2, ChemAxon (2009).http://www.chemaxon.com.

[34] C. Abad-Zapatero, Ligand efficiency indices for effective drug discovery, Expert Opin. Drug Discov. 2 (2007) 469-488.

[35] C. Abad-Zapatero, J.T. Metz, Ligand efficiency indices as guideposts for drug discovery, Drug Discov. Today 10 (2005) 464-469.

[36] T. Mineva, V. Parvanov, I. Petrov, N. Neshev, N. Russo, Fukui indices from perturbed Kohn-Sham orbitals and regional softness from mayer atomic valences, J. Phys. Chem. A 105 (2001) 1959-1967.

[37] C. Teixeira, J.R. Gomes, T. Couesnon, P. Gomes, Molecular docking and 3D-quantitative structure activity relationship analyses of peptidyl vinyl sulfones: Plasmodium falciparum cysteine proteases inhibitors, J. Comput. Aided Mol. Des 25 (2011) 763-775.

[38] J.P. Reeves, Accumulation of amino acids by lysosomes incubated with amino acid methyl esters, J. Biol. Chem. 254 (1979) 8914-8921.

[39] R.A. Kavishe, J.M. van den Heuvel, M. van de Vegte-Bolmer, A.J. Luty, F.G. Russel, J.B. Koenderink, Localization of the ATP-binding cassette (ABC) transport proteins PfMRP1, PfMRP2, and PfMDR5 at the Plasmodium falciparum plasma membrane, Malar. J. 8 (2009) 205.

[40] R.E. Martin, R.V. Marchetti, A.I. Cowan, S.M. Howitt, S. Broer, K. Kirk, Chloroquine transport via the malaria parasite's chloroquine resistance transporter Science 325 (2009) 1680-1682.

[41] R.E. Martin, H. Ginsburg, K. Kirk, Membrane transport proteins of the malaria parasite, Mol. Microbiol. 74 (2009) 519-528.

[42] S. Baumeister, M. Winterberg, C. Duranton, S.M. Huber, F. Lang, K. Kirk K. Lingelbach, Evidence for the involvement of Plasmodium falciparum proteins in the formation of new permeability pathways in the erythrocyte membrane, Mol. Microbiol. 60 (2006) 493-504.

[43] J.A. Naughton, S. Nasizadeh, A. Bell, Downstream effects of haemoglobinase inhibition in Plasmodium falciparum-infected erythrocytes, Mol. Biochem. Parasitol. 173 (2010) 81-87.

[44] S. McGowan, C.A. Oellig, W.A. Birru, T.T. Caradoc-Davies, C.M. Stack, J. Lowther T. Skinner-Adams, A. Mucha, P. Kafarski, J. Grembecka, K.R. Trenholme, A.M. Buckle, D.L. Gardiner, J.P. Dalton, J.C. Whisstock, Structure of the Plasmodium falciparum M17 aminopeptidase and significance for the design of drugs targeting the neutral exopeptidases, Proc. Natl. Acad. Sci. U S A 107 (2010) 2449-2454

[45] J. Kanaani, H. Ginsburg, Effects of cinnamic acid derivatives on in vitro growth of Plasmodium falciparum and on the permeability of the membrane of malaria-infected erythrocytes, Antimicrob. Agents Chemother. 36 (1992) 1102-1108.

[46] R.H. Hans, J. Gut, P.J. Rosenthal, K. Chibale, Comparison of the antiplasmodial and falcipain- 2 inhibitory activity of beta-amino alcohol thiolactone-chalcone and isatin-chalcone hybrids, Bioorg. Med. Chem. Lett. 20 (2010) 2234-2237.

[47] E.M. Guantai, K. Ncokazi, T.J. Egan, J. Gut, P.J. Rosenthal, R. Bhampidipati, A. Kopinathan, P.J. Smith, K. Chibale, Enone- and chalcone-chloroquinoline hybrid analogues: in silico guided design, synthesis, antiplasmodial activity, in vitro metabolism, and mechanistic studies, J. Med. Chem. 54 (2011) 3637-3649.

[48] J.M. Coteron, D. Catterick, J. Castro, M.J. Chaparro, B. Diaz, E. Fernandez, S. Ferrer, F.J. Gamo, M. Gordo, J. Gut, L. de las Heras, J. Legac, M. Marco, J. Miguel, V. Munoz, E. Porras, J.C. de la Rosa, J.R. Ruiz, E. Sandoval, P. Ventosa, P.J. Rosenthal, J.M. Fiandor, Falcipain inhibitors: optimization studies of the 2-pyrimidinecarbonitrile lead series, J. Med. Chem. 53 (2010) 6129-6152.

[49] B.R. Shenai, P.S. Sijwali, A. Singh, P.J. Rosenthal, Characterization of native and recombinant falcipain-2, a principal trophozoite cysteine protease and essential hemoglobinase of Plasmodium falciparum, J. Biol. Chem. 275 (2000) $29000-29010$.

[50] P.S. Sijwali, B.R. Shenai, J. Gut, A. Singh, P.J. Rosenthal, Expression and characterization of the Plasmodium falciparum haemoglobinase falcipain-3. Biochem. J. 360 (2001) 481-489.

[51] G. Jones, P. Willett, R.C. Glen, A.R. Leach, R. Taylor, Development and validation of a genetic algorithm for flexible docking, J. Mol. Biol. 267 (1997) 727-748.

[52] J.C. Gordon, J.B. Myers, T. Folta, V. Shoja, L.S. Heath, A. Onufriev, H++: a server for estimating pKas and adding missing hydrogens to macromolecules, Nucleic Acids Res. 33 (2005) W368-W371.

[53] D.A. Case, T.A. Darden, T.E. Cheatham, C.L.I. Simmerling, J. Wang, R.E. Duke, R. Luo, M. Crowley, R.C. Walker, W. Zhang, K.M. Merz, B. Wang, S. Hayik, A. Roitberg, G. Seabra, K.F. Kolossváry, K.F. Wong, F. Paesani, F. Vanicek, X. Wu, S.R. Brozell, T. Steinbrecher, H. Gohlke, L. Yang, C. Tan, J. Mongan, V. Hornak, G. Cui, D.H. Mathews, M.G. Seetin, C. Sagui, V. Babin, P.A. Kollman, AMBER 10 University of California, San Francisco, 2008. 
[54] Y. Duan, C. Wu, S. Chowdhury, M.C. Lee, G. Xiong, W. Zhang, R. Yang, P. Cieplak, R. Luo, T. Lee, J. Caldwell, J. Wang, P. Kollman, A point-charge force field for molecular mechanics simulations of proteins based on condensedphase quantum mechanical calculations, J. Comput. Chem. 24 (2003) 1999-2012.

[55] J. Wang, R.M. Wolf, J.W. Caldwell, P.A. Kollman, D.A. Case, Development and testing of a general amber force field, J. Comput. Chem. 25 (2004) 1157-1174.

[56] T. Fox, P.A. Kollman, Application of the RESP methodology in the parametrization of organic solvents, J. Phys. Chem. B 102 (1998) 8070-8079.

[57] M.J.T. Frisch, G.W. Trucks, H.B. Schlegel, G.E. Scuseria, M.A. Robb, J.R. Cheeseman, J.A. Montgomery Jr., T. Vreven, K.N. Kudin, J.C. Burant, J.M. Millam, S.S. Iyengar, J. Tomasi, V. Barone, B. Mennucci, M. Cossi, G. Scalmani, N. Rega, G.A. Petersson, H. Nakatsuji, M. Hada, M. Ehara, K. Toyota, R. Fukuda, J. Hasegawa, M. Ishida, T. Nakajima, Y. Honda, O. Kitao, H. Nakai, M. Klene, X. Li, J.E. Knox, H.P. Hratchian, J.B. Cross, C. Adamo, J. Jaramillo, R. Gomperts, R.E. Stratmann, O. Yazyev,
A.J. Austin, R. Cammi, C. Pomelli, J.W. Ochterski, P.Y. Ayala, K. Morokuma, G.A. Voth, P. Salvador, J.J. Dannenberg, V.G. Zakrzewski, S. Dapprich, A.D. Daniels, M.C. Strain, O. Farkas, D.K. Malick, A.D. Rabuck, K. Raghavachari, J.B. Foresman, J.V. Ortiz, Q. Cui, A.G. Baboul, S. Clifford, J. Cioslowski, B.B. Stefanov, G. Liu, A. Liashenko, P. Piskorz, I. Komaromi, R.L. Martin, D.J. Fox, T. Keith, M.A. Al-Laham, C.Y. Peng, A. Nanayakkara, M. Challacombe, P.M.W. Gill, B. Johnson, W. Chen, M.W. Wong, C. Gonzalez, J.A. Pople, Gaussian 03, Gaussian, Inc., Pittsburgh PA, 2003.

[58] A.E. Reed, R.B. Weinstock, F. Weinhold, Natural-population analysis, J. Chem. Phys. 83 (1985) 735-746.

[59] A.D. Becke, Density-functional thermochemistry 3. The role of exact exchange, J. Chem. Phys. 98 (1993) 5648-5652.

[60] P.J. Stephens, F.J. Devlin, C.F. Chabalowski, M.J. Frisch, Ab-initio calculation of vibrational absorption and circular-dichroism spectra using densityfunctional force-fields, J. Phys. Chem. 98 (1994) 11623-11627. 